\title{
Buruli Ulcer: History and Disease Burden
}

\author{
Katharina Röltgen and Gerd Pluschke
}

\section{$1 \quad$ History of a Mysterious Skin Disease}

The first description of chronic skin ulcers consistent with the pathology of Mycobacterium ulcerans infection dates back to the end of the nineteenth century, when the British physician Albert Cook recorded his observations in The Mengo Hospital Notes, maintained in the library of the hospital in Kampala, Uganda [1]. In 1948, characteristics of similar skin ulcers were described by MacCallum and his colleagues in six patients from the Bairnsdale District in southeastern Australia [2], where the disease is therefore often referred to as Bairnsdale ulcer. The causative organism isolated from these ulcers was found to be an acid-fast mycobacterium, later named M. ulcerans. Noteworthy, the first isolation of the extremely slowgrowing mycobacterium in culture was achieved by accidental incubation of culture plates in a faulty incubator [3], reflecting the low optimal growth temperature of the pathogen at $30-33{ }^{\circ} \mathrm{C}$. This temperature preference is considered a major factor for the skin tropism and limited systemic dissemination of M. ulcerans infections. In the 1940s and 1950s a larger case series of 170 patients with necrotic skin ulcers, caused by an acid-fast mycobacterium, was recorded in the Democratic Republic of the Congo [4]. A high prevalence of M. ulcerans infections was noticed in the 1950s and 1960s in a geographically very limited area of the then sparsely populated Buruli County close to the Nile River in Uganda and as a consequence, the disease became more generally known as Buruli ulcer (BU) $[5,6]$. In proximity to this initial infection focus, a second outbreak of the disease in Uganda was reported in Rwandans living in a refugee settlement that was opened in 1964 close to the Nile

\footnotetext{
K. Röltgen $\cdot$ G. Pluschke $(\bowtie)$

Swiss Tropical and Public Health Institute, Basel, Switzerland

University of Basel, Basel, Switzerland

e-mail: gerd.pluschke@swisstph.ch 
River. Intensive investigation of the 220 BU cases that occurred until 1969, when the community moved to a new locality, where case numbers declined, has provided much of the basic knowledge about the epidemiology of BU that is still valid today. Amongst other insights it became apparent that BU may affect individuals irrespective of sex and age, although the highest incidence was seen in children aged between 5 and 15 years. Furthermore, in contrast to a very low probability of person to person transmission, the involvement of an environmental reservoir in the transmission became obvious [7]. While until then clinical attention had been concentrated on ulcerative lesions, awareness of the disease in highly endemic regions has brought attention to pre-ulcerative forms of the infection including nodules, plaques and edema [8].

Until the end of the twentieth century, BU case series were reported mainly from West and Central African countries including the Congo [9], Nigeria [10], Gabon [11], Ghana [12, 13], Benin [14], and Côte d'Ivoire [15, 16] as well as from Australia [17, 18] and Papua New Guinea (PNG) [19]. Moreover, sporadic M. ulcerans infections occurred in a number of additional countries with tropical, subtropical and temperate climates [20], totalling up to 34 countries from which BU has hitherto been reported. However, limited awareness of the disease and the fact that it often affects poor populations in remote, rural areas has hampered the detection of new infection foci and thus the control of BU. In 1998, WHO launched the Global BU Initiative, a partnership of Member States, academic and research institutions, donors, nongovernmental organizations, WHO, and others with the intention to raise awareness and to coordinate global BU control and multidisciplinary research efforts. In addition, this Initiative was meant to strengthen BU surveillance systems and to assess the disease burden at local, national and global levels. More than 58,000 BU cases had been reported between 2002 and 2016 from 20 countries in Africa (Benin, Cameroon, Central African Republic, Congo, Côte d'Ivoire, Democratic Republic of the Congo, Equatorial Guinea, Gabon, Ghana, Guinea, Liberia, Nigeria, Sierra Leone, South Sudan, Uganda and Togo), the Americas (French Guiana), Asia (Japan), and the Western Pacific (Australia and PNG) (Table 1). Since 2008, a steady decline in the number of reported BU patients has been noticed (Fig. 1).

While this may in part be due to the establishment of effective national BU control programs, underreporting is considered likely, as there is lack of data from an increasing number of countries that have reported BU cases in the past. Moreover, surveillance activities in some of the highly endemic countries may have declined due to the decreased availability of specific funding. On the contrary, a steady increase in the number of BU patients has been reported from the BU endemic region of Victoria in southern Australia, with a peak incidence of 186 new BU infections in 2016. The geographic distribution of BU recorded by WHO in 2016 is illustrated in Fig. 2. 


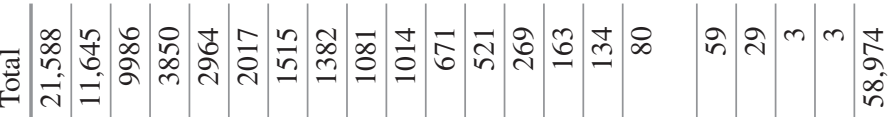

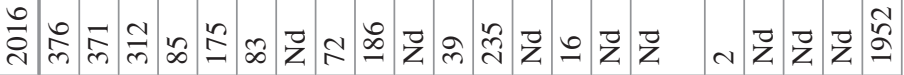

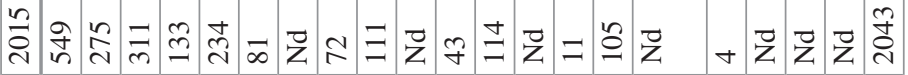

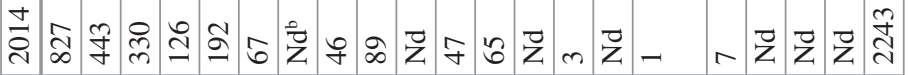

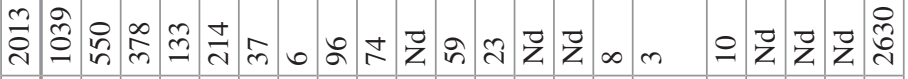

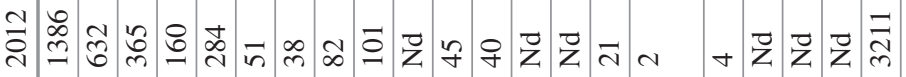

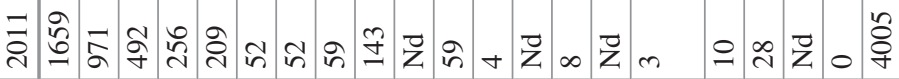

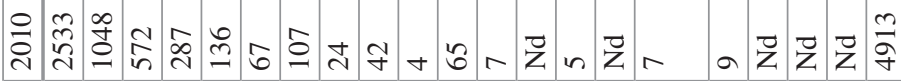

ठ্خे

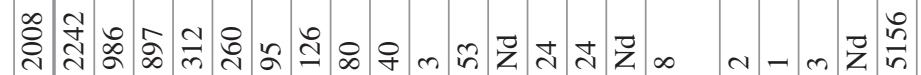

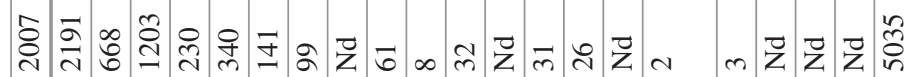

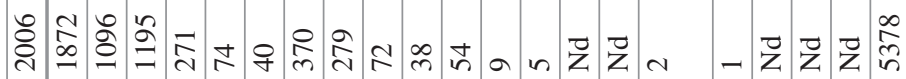

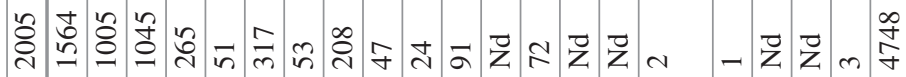

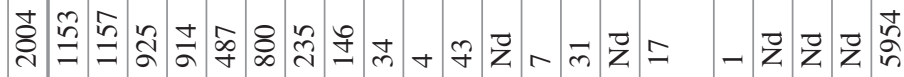

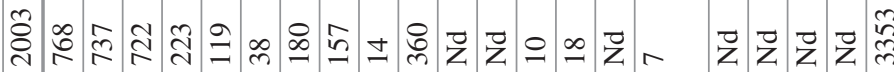

(

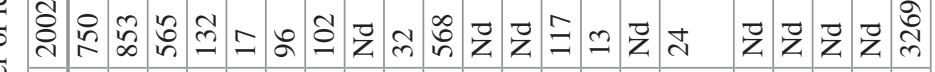

离 
Fig. 1 Number of BU cases reported worldwide between 2002 and 2016. Graph illustrating the downward trend of new M. ulcerans infections reported in the past years. Data source: WHO

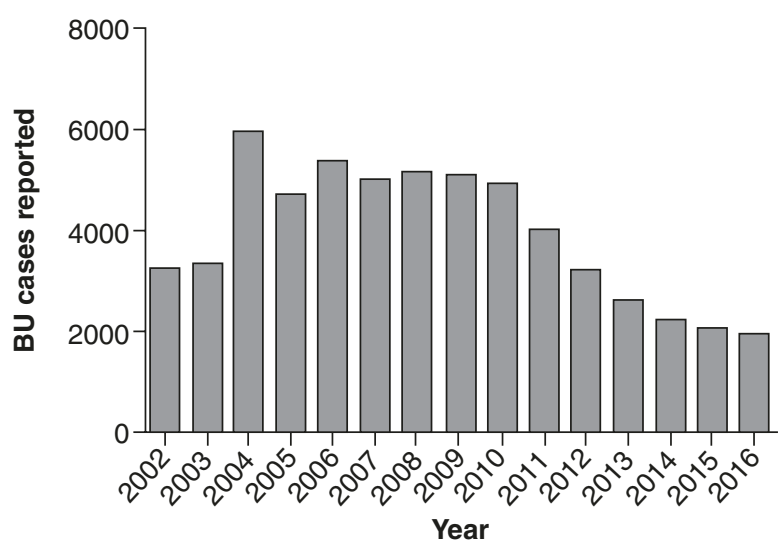

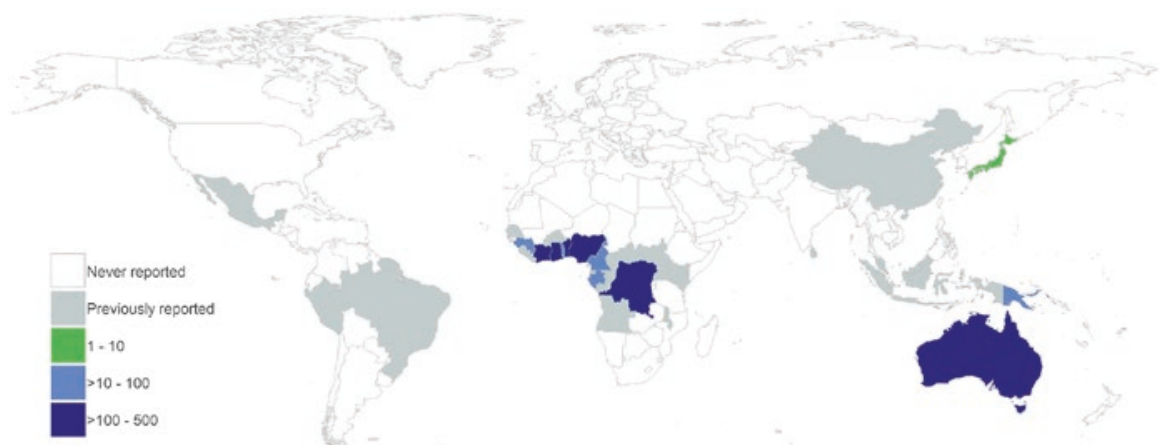

Fig. 2 Worldwide distribution of BU cases in 2016. Global map illustrating countries that have reported cases in 2016 (blue (classical lineage) and green (ancestral lineage)) and in previous years (grey). The map was kindly created by Dr. K. Ampah using 'R'. Data source: WHO

\section{Evolution, Niche Adaptation, and Transmission of Distinct M. ulcerans Lineages}

The emergence of $M$. ulcerans, which has evolved from the fish and opportunistic human pathogen $M$. marinum [21] approximately a million years ago [22], was driven by horizontal transfer of genetic material [21]. Most notably, this included a virulence plasmid, carrying genes for the synthesis of macrolide toxins, whose cytotoxic and immunosuppressive properties account for much of the typical progressive skin necrosis and chronicity of $M$. ulcerans infections. Several structural variants of these mycolactones have hitherto been described [23-25]; for more information on the toxin of $M$. ulcerans the reader is referred to chapter 
"Mycolactone: More than Just a Cytotoxin" of this book. Moreover, acquisition of high-copy number insertion sequences (IS2404 and IS2606) and their expansion in the $M$. ulcerans genome has resulted in extensive gene loss, pseudogene formation, and modification of gene function, coining the likely adaptation to new, restricted, ecological niches [26]. For more detailed information on the population genomics and molecular epidemiology of M. ulcerans the reader is referred to chapter "Population Genomics and Molecular Epidemiology of Mycobacterium ulcerans" of this book. During the process of its genome reduction, $M$. ulcerans has diverged into at least two principal lineages [27], the ancestral and the classical lineage, which presumably have been adapting to distinct niche environments within the aquatic ecosystem [26]. Both lineages can cause severe tissue destruction if lesions are left untreated (Fig. 3).

Until today, the exact source of the infection is not clear, in part because cultivation of $M$. ulcerans from potential environmental sources is hindered by the extremely slow growth rate of the pathogen. The marked loss of gene function as compared to the genome of $M$. marinum, including genes required for pigment biosynthesis and anaerobiosis [26], indicates that $M$. ulcerans may exist as a commensal associated with a protective organism in the ecosystem [28-30]. Despite extensive research, the mode(s) of transmission from environmental reservoirs to mammalian hosts is unclear. It is thus likely that $M$. ulcerans may be transmitted by several distinct mechanisms, each enabling the entrance of a sufficient pathogen load into the susceptible layers of subcutaneous tissue.

\subsection{Ancestral M. ulcerans Lineage}

Strains of the ancestral lineage, which are closely related to M. marinum, mainly cause disease in ectotherms such as fish and frogs [25, 31-33], but certain subgroups sporadically infect humans. Due to their distinct host range, some mycolactone-producing ancestral strains were initially given different species designations such as $M$. marinum for globally detected fish pathogens [25], $M$. pseudoshottsii for mycobacteria isolated from diseased Chesapeake Bay striped bass [32], or M. liflandii for strains isolated during a mycobacteriosis outbreak in a laboratory colony of Xenopus tropicalis [31]. Furthermore, ancestral strains isolated from the lesions of BU patients from Japan are often referred to as M. ulcerans subspecies shinshuense [34]. Indeed, comparative genome analysis has shown that based on the sequences of fish and frog isolates on the one hand and human disease isolates from Japan on the other hand the ancestral lineage may be subdivided into two major sub-lineages [26]. The common feature of all of these isolated pathogens is the production of mycolactone and thus it was no surprise when comparative genome analysis of ancestral and classical M. ulcerans strains has revealed that all mycolactone-producing mycobacteria have evolved from a common $M$. marinum-like progenitor and should therefore be considered as ecovars of a single $M$. ulcerans species $[26,35]$. Ecovars of the ancestral lineage appear to 

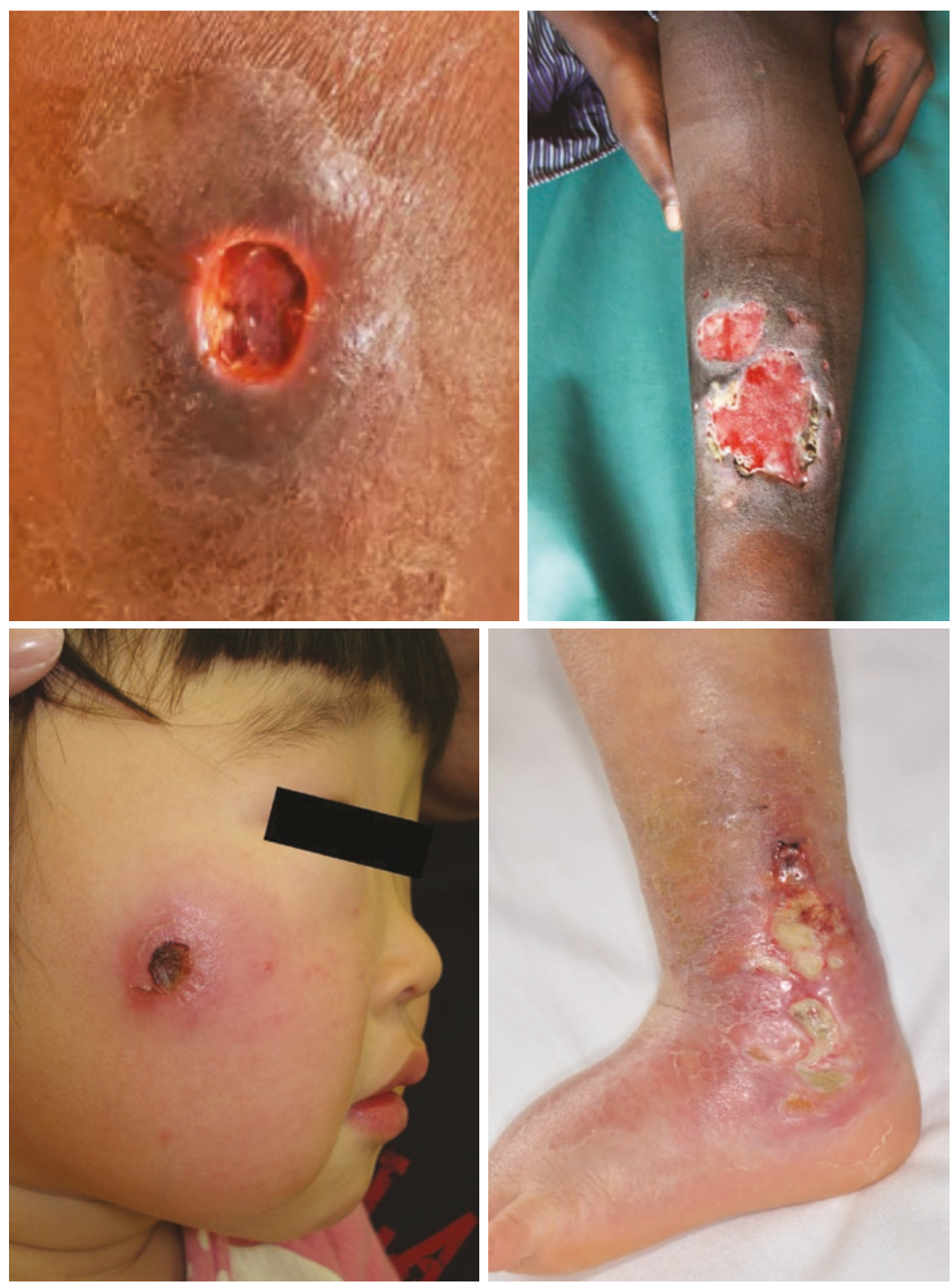

Fig. 3 Ulcerative BU lesions in patients from West Africa (upper panel) and Japan (lower panel). Photographs from Japanese patients were kindly provided by Dr. M. Ohtsuka, Fukushima Medical University 
be adapting to an ecological niche environment, from which they infect humans only occasionally. Environmental studies in regions where the ancestral lineage of M. ulcerans prevails are still in their infancy. However, in French Guiana, $M$. ulcerans-specific DNA sequences (IS2404 and the ketoreductase-B domain of the M. ulcerans mycolactone polyketide synthase genes (KR)) were found in different freshwater bodies [36]. In Japan, an outbreak of BU among several family members was linked to a stagnant water channel in the backyard of the family's house, in which a sample of a crayfish contained an IS2404 sequence identical to that of M. ulcerans [37].

Sporadic human infections caused by ancestral strains were reported from the Americas (French Guiana [36], Suriname [38], Peru [39], Brazil [40] and Mexico [41]) and from Asia (Japan [42] and China [43]). Between 2002 and 2016, French Guiana and Japan reported to WHO 80 and 59 BU cases, respectively. No official records are available for the other South-American and Asian countries. For more detailed information on BU in French Guiana and Japan the reader is referred to chapters "Mycobacterium ulcerans Infection in French Guiana; Current State of Knowledge" and "Buruli Ulcer in Japan" of this book.

\subsection{Classical M. ulcerans Lineage}

Strains of the classical lineage are responsible for the vast majority of human $M$. ulcerans infections, reported mainly from Africa [20], Australia [17, 18, 44], and PNG $[19,45,46]$. Considering the often very high local prevalence of BU in African and Australian endemic regions, the classical lineage may be present in an environmental reservoir that - compared to ecovars of the ancestral lineage-is associated with a higher risk for humans to contract an infection. Some environmental investigations in African BU endemic areas have shown that M. ulcerans-specific DNA sequences can be detected in many biotic components of aquatic ecosystems, such as plants, snails, fish, or insects pointing towards the ubiquitous presence of the pathogen in these ecosystems [47]. For reasons that are currently not clear, the detection rate was much smaller in other environmental studies in African BU endemic areas $[48,49]$. Studies in southeastern Australia have revealed that possums are highly susceptible to $M$. ulcerans infection. Sporadic infections have also been found in other native wildlife and domestic mammals [50, 51]. For more detailed information on BU in animals the reader is referred to chapter "Buruli Ulcer in Animals and Experimental Infection Models" of this book. Infected possums were shown to harbour high loads of M. ulcerans DNA in their gastrointestinal tracts. However, M. ulcerans cultivation from faeces failed, while being successful from skin lesions of infected possums [50, 51]. Genome comparison of classical lineage $M$. ulcerans isolates from possums and humans revealed an extremely close 
genetic relationship, supporting a role for these animals in the ecology of infection as a reservoir of the pathogen [26]. In Far North Queensland (FNQ), another BU endemic area of Australia, M. ulcerans DNA was detected in excreta of bandicoots [52]. These findings suggest that certain Australian marsupials may be highly susceptible to $M$. ulcerans infection. In contrast, until today, surveys of small mammals in African BU endemic areas have not led to the detection of an M. ulcerans animal reservoir $[48,53]$. It has been suspected that in highly endemic areas of Africa, large chronic lesions of BU patients may contribute significantly to the dissemination of M. ulcerans in the environment.

Between 2002 and 2016, a total of 57,591 BU cases were reported from 16 African countries, 1081 from Australia and 163 from PNG. No official records are available for other countries, in which the presence of classical M. ulcerans infections was suspected, such as Kiribati [54] or Malaysia [55]. For more detailed information on BU in Africa and Australia the reader is referred to chapters "Buruli Ulcer in Africa" and "Buruli Ulcer in Australia" of this book.

\section{Characteristics of BU Disease in Humans}

In the following paragraphs, relevant data for BU disease in different BU endemic areas are compiled to enable a comparison of epidemiological and clinical features as well as environmental characteristics. For that purpose, PubMed was searched using the query "Buruli ulcer" OR "Mycobacterium ulcerans". All titles ( $\mathrm{N}=\sim 1180)$ and available abstracts were screened for relevant content. Studies including more than 30 BU cases were used to extract information on demographic and geographic features of BU in these areas. In view of the multitude of publications on African BU endemic settings, representative studies conducted in eight different countries were selected. We included at least one and not more than three studies from the seven countries that have reported the vast majority of BU cases in the past decade, namely Côte d'Ivoire [56], Ghana [57-59], Benin [6062, 76], Cameroon [63, 64], Democratic Republic of the Congo [65], Togo [66] and Republic of the Congo [67] as well as a case series from Nigeria [68], one of the few countries, which has recorded an increase in the number of reported cases over the past years. Studies were selected based on a preference for (1) quantity of BU cases (large case series), (2) quality (preferentially studies including laboratory-confirmed patients), (3) content (data on many epidemiological aspects), and (4) "up-to-datedness" (recent publications, if available and complying with other preferences). Furthermore, a very detailed study of 220 BU cases that were identified within a community of Rwandan refugees between 1964 and 1969 near the river Nile in Central Uganda was included [7] (Tables 2 and 3). BU endemic regions outside of Africa included in this comparative analysis are French Guiana (chapter "Mycobacterium ulcerans Infection in French Guiana; Current State of Knowledge" of this book) [69], Japan [42] (chapter "Buruli Ulcer in Japan" of this book), PNG [19, 46], FNQ, Australia [44, 70] and Victoria, Australia [71, 72] (chapter "Buruli Ulcer in Australia" of this book). 


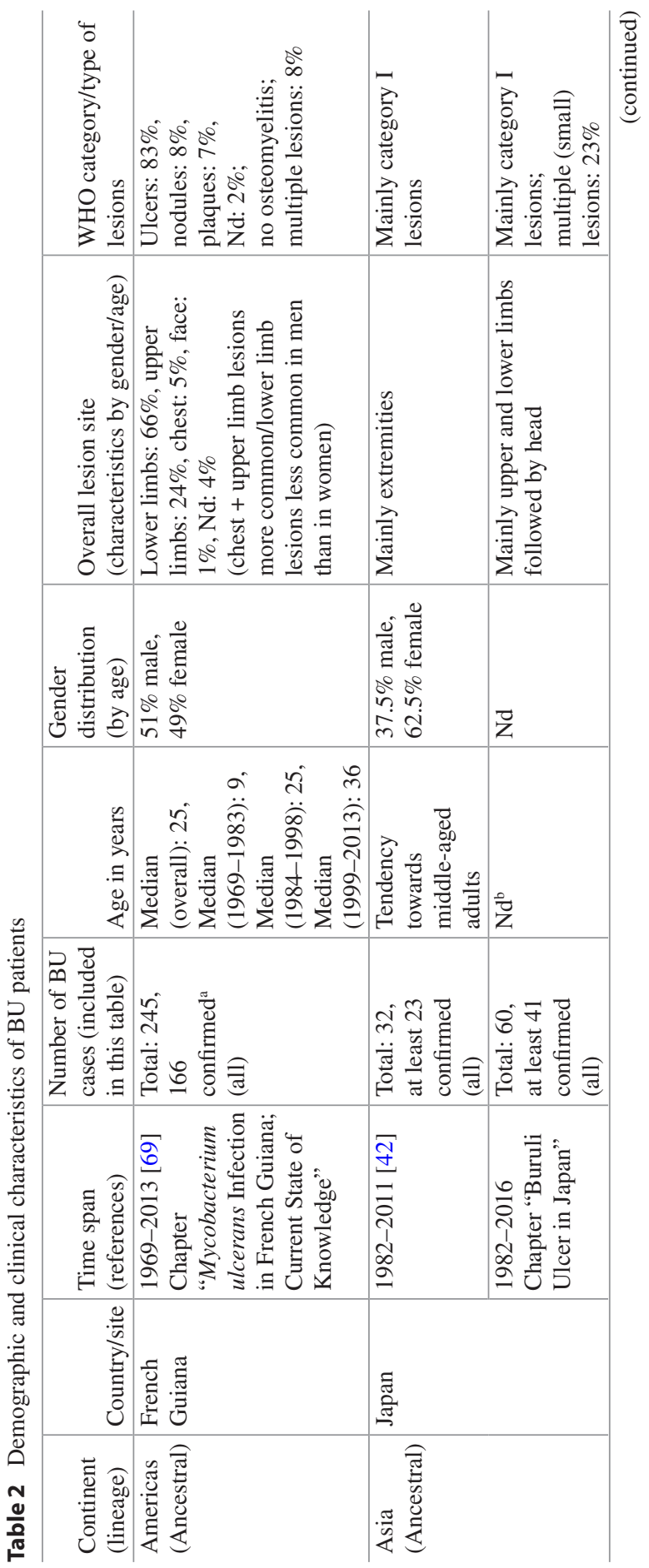




\begin{tabular}{|c|c|c|c|c|c|c|}
\hline 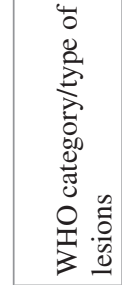 & 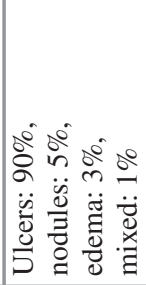 & 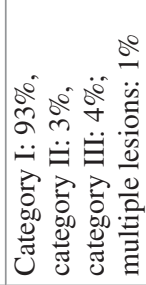 & 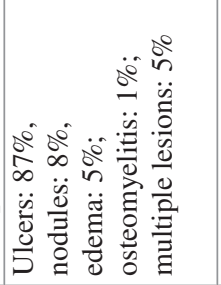 & 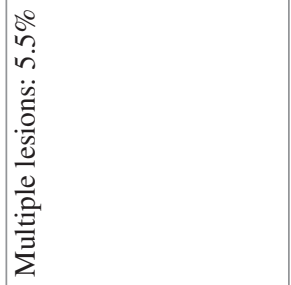 & 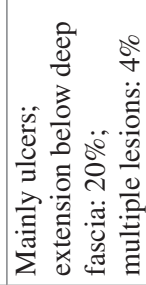 & $\vec{z}$ \\
\hline 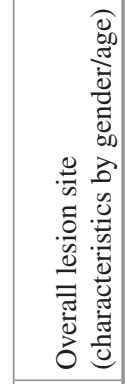 & 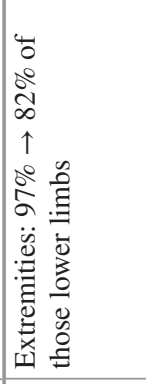 & 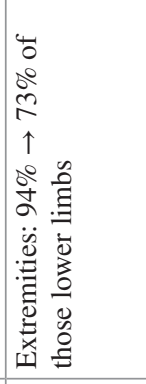 & 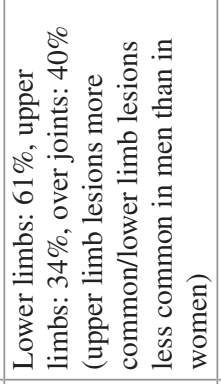 & 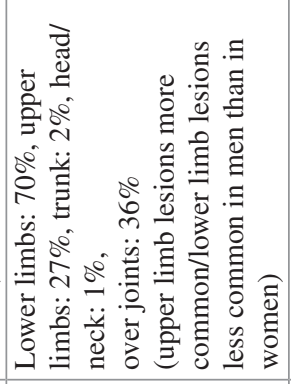 & 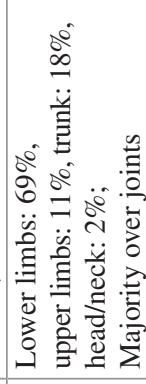 & 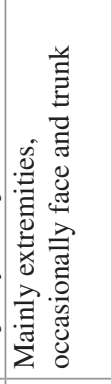 \\
\hline 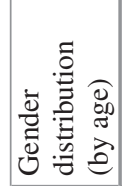 & 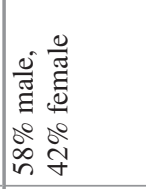 & 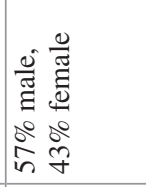 & 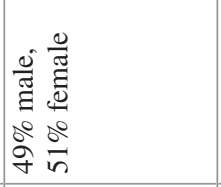 & 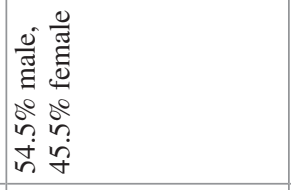 & 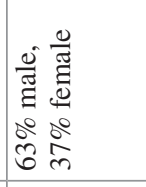 & 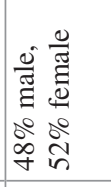 \\
\hline 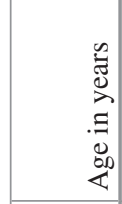 & 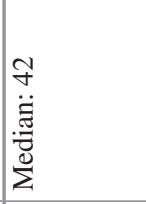 & 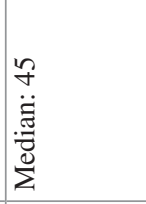 & 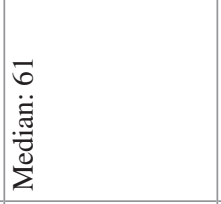 & 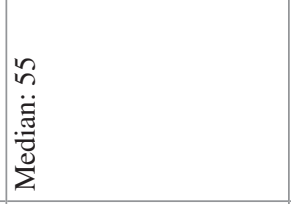 & 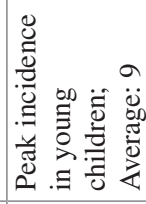 & 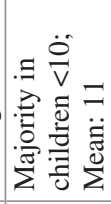 \\
\hline 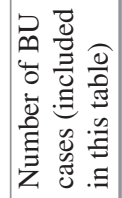 & 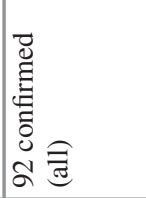 & 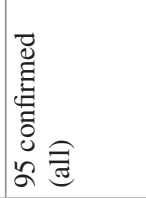 & 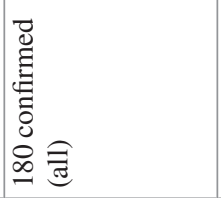 & 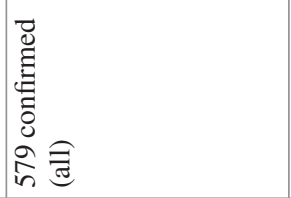 & 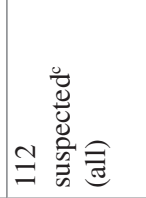 & 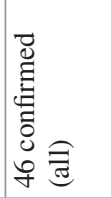 \\
\hline 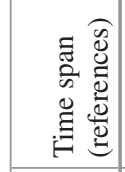 & 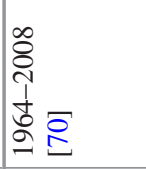 & 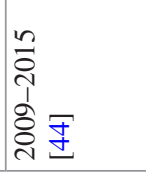 & 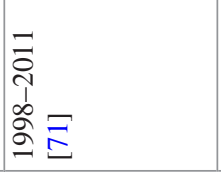 & 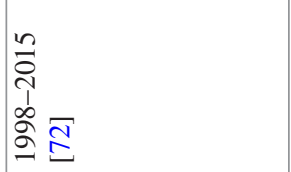 & 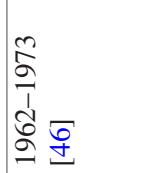 & 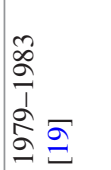 \\
\hline 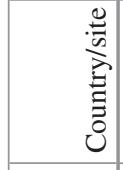 & $\underset{I I}{O}$ & & $\frac{.0}{\tilde{0}}$ & & Z & \\
\hline 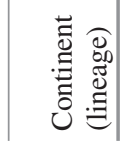 & 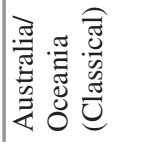 & & & & & \\
\hline
\end{tabular}




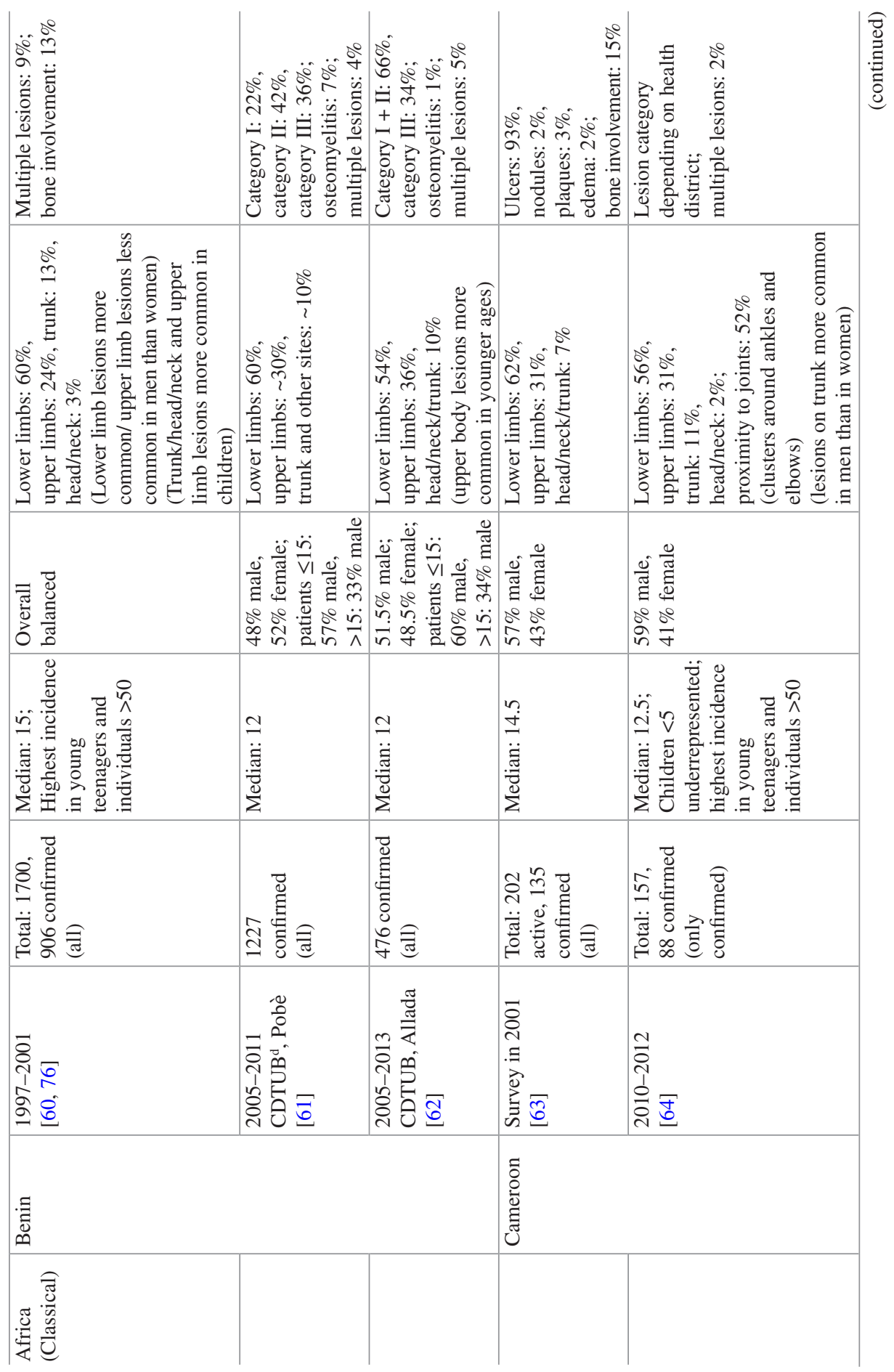




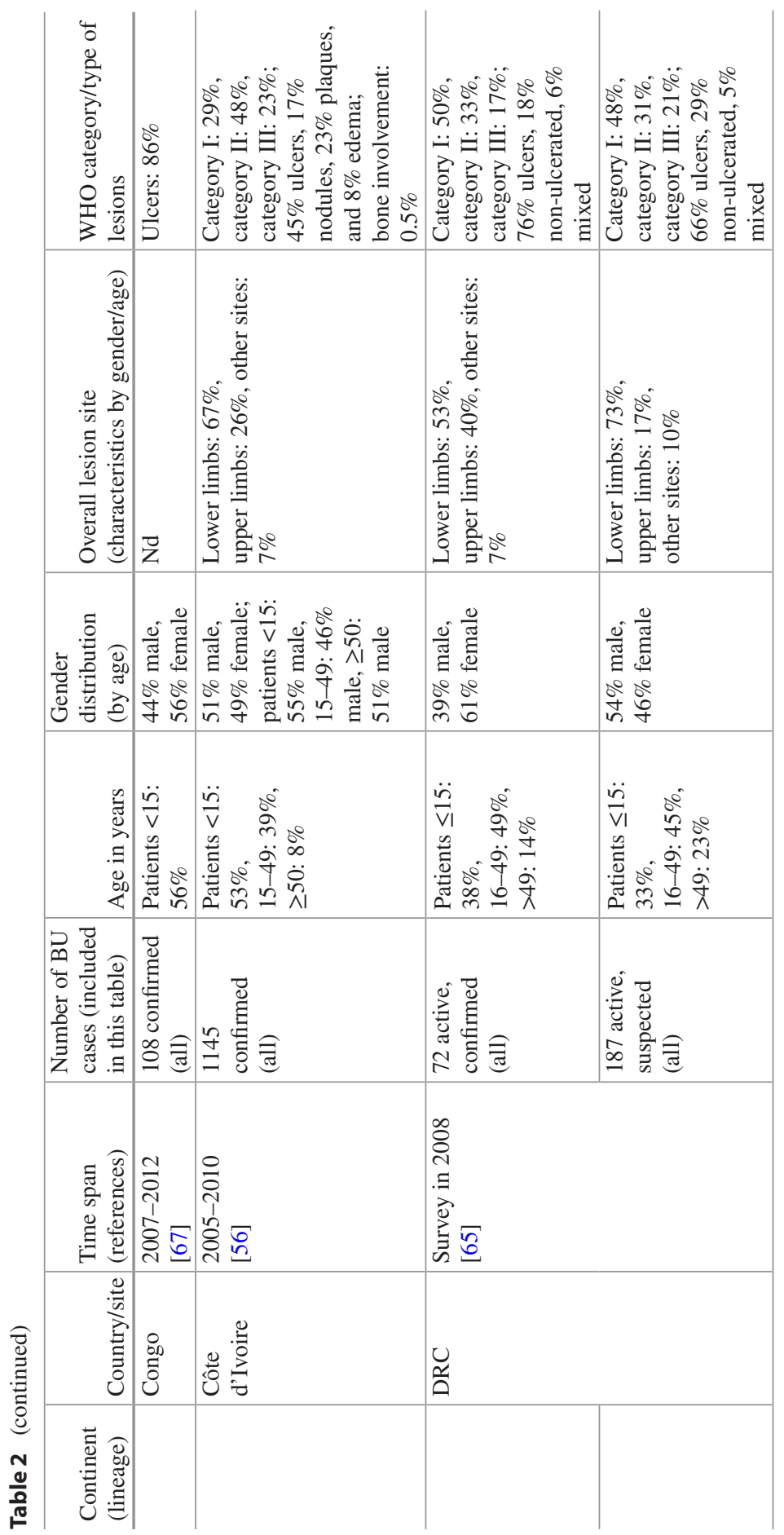




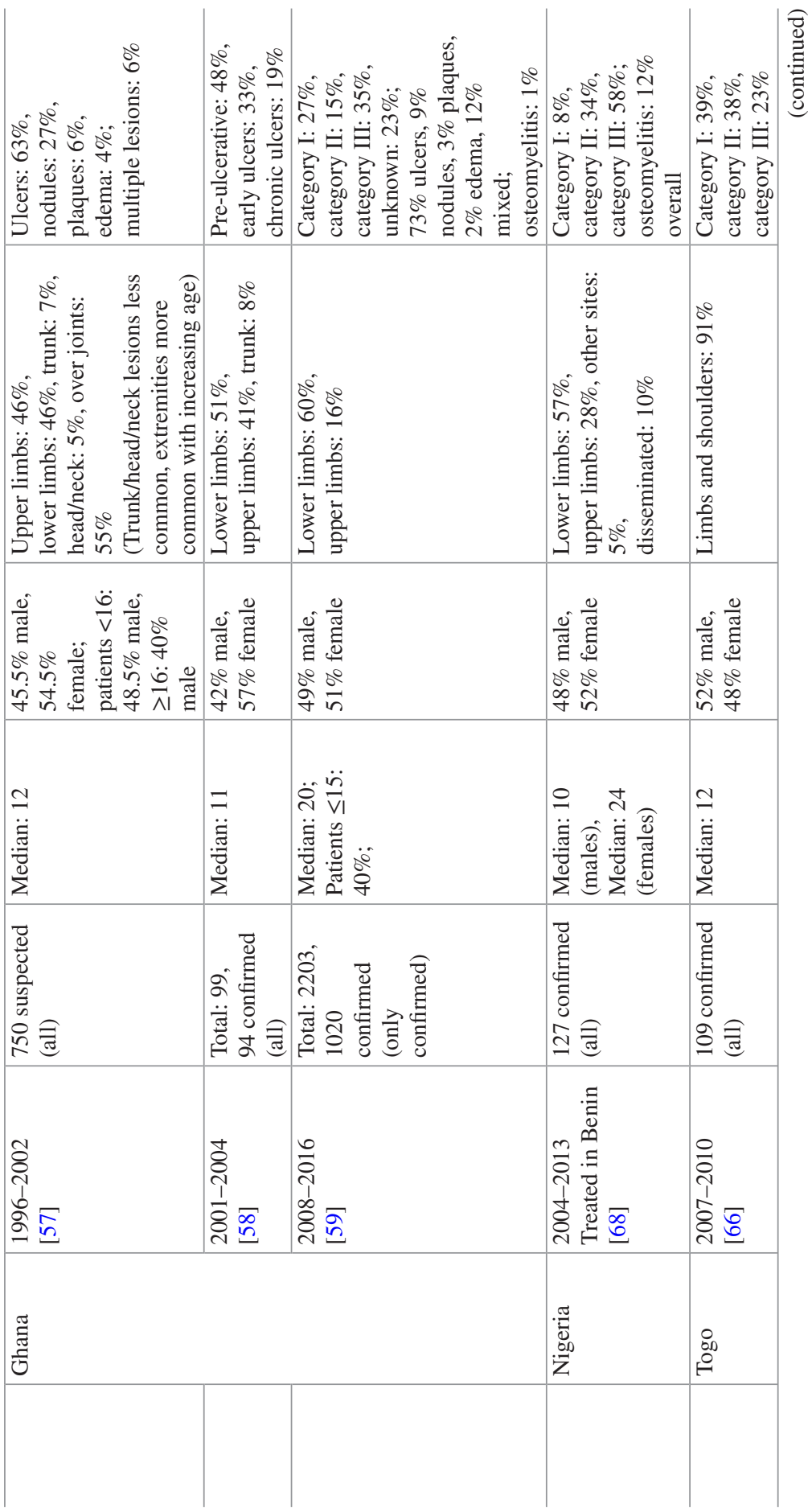




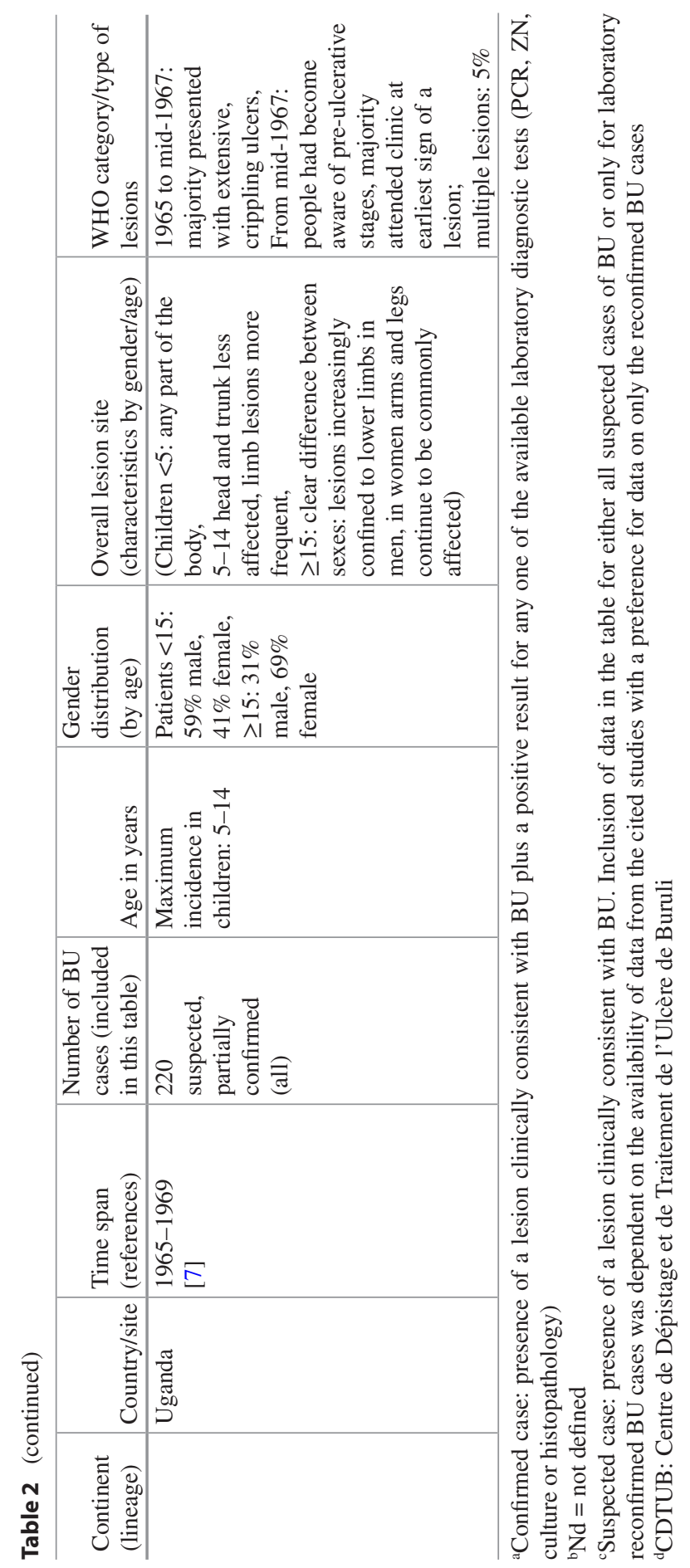




\subsection{Demographic and Clinical Characteristics of $M$. ulcerans Infection}

\subsubsection{Age Distribution of BU Patients}

$\mathrm{BU}$ has long been considered as a disease that mainly affects children under the age of 15 years living in rural areas of Africa. A comparison of the age distribution reported for various BU case series (Table 2) shows that this assumption still holds true for African BU endemic areas and for endemic sites in PNG. However, this generalized view lapsed when larger case series were reported from Victoria in southeastern Australia, where a high average age of BU patients was observed (Table 2). The peak incidence of BU among children in Africa and the elderly in Victoria may be partly related to the average age of the respective general populations in the affected areas. While the population in BU endemic areas in Africa is very young $[64,73,74]$, the affected communities in Victoria are popular seaside holiday resorts, where many retired people have their homes. But even if taking the skewed age distribution of the study populations into account, the elderly were most affected in Australia [75] and a bi-modal distribution of the age-related risk of developing BU was observed in Africa with young teenagers and the elderly being overrepresented among cases $[64,74,76]$. Increasing risk of developing $\mathrm{BU}$ with age may be due to the gradual deterioration of the immune system in the elderly. Interestingly, a marked underrepresentation of BU patients among children below 4 years of age was found [64]. This observation was in line with subsequent sero-epidemiological studies in Ghana and Cameroon, indicating that young children are considerably less exposed to M. ulcerans than older children [77, 78].

In Japan, where BU disease is caused by strains of the ancestral M. ulcerans lineage, a tendency towards middle-aged adults was found [42]. In French Guiana, a marked transition of the most affected age groups was observed: over a period of 45 years the median age of patients increased significantly from 9 years of age in the study period between 1969 and 1983 to 36 years of age between 1999 and 2013 [69]. Taken together the age-related risk of developing BU appears to be determined both by differential exposure to M. ulcerans and by higher susceptibility of certain age groups.

\subsubsection{Gender Distribution of BU Patients}

A comparison of various BU case series (Table 2) reveals an overall balanced male:female ratio among patients, although in some studies the proportion of one of the sexes was higher than that of the other. While more female than male patients were recorded in Japan, more men than women tended to be affected in FNQ, Australia. Several studies conducted with large numbers of African BU cases revealed significant differences in the male:female ratio, when the study population was stratified by age. All of these studies have consistently reported that in children below the age of 15 years, M. ulcerans infection is more common in boys than in girls and conversely that in individuals above the age of 15 years the infection is more frequent in females than in males [7, 56, 61, 62] (Table 2). It appears likely 
that observed differences are due to different environmental contact patterns associated with the movement radius of children or different occupational exposure to environmental reservoirs.

\subsubsection{Distribution of BU Lesions on the Human Body}

While the mode of transmission of M. ulcerans remains unclear, it is commonly assumed that infection takes places via inoculation of the bacteria into the skin through direct trauma or bites of insects such as water bugs or mosquitoes [47, 51]. The site of inoculation is thought to be also the site of infection, not least because about $95 \%$ of BU patients present with a single lesion. A disseminated disease progression may only be found in those $5 \%$ of the patients presenting with multiple lesions (Table 2). Therefore, the location of BU lesions on the body of patients has been extensively studied, with the hope of detecting specific distribution patterns, such as a clustering of lesions at preferred feeding sites of biting arthropods vs. common sites for mechanical skin injuries, favouring any of the discussed mechanisms of infection. BU lesions, irrespective of whether they are caused by strains of the ancestral or the classical $M$. ulcerans lineage, occur mostly on parts of the body, which are not commonly protected by clothing (Table 2 ). The vast majority of studies found that lesions occurred in $90 \%$ or more of the cases on the limbs. Around two-thirds of the lesions occurred on the lower limbs, followed by the upper limbs, and less frequently the trunk, and sites on the neck/head (Table 2). While overall patterns observed in different regions, such as for example in Cameroon and Victoria, Australia appear to be surprisingly similar [64, 72], several studies have reported that the anatomical site of the lesions may vary with both gender and age. Interestingly, in studies conducted in French Guiana and Victoria upper limb lesions were more common in men than in women, who were more frequently affected on the lower limbs than were men [69, 71, 72]. Conversely, in African BU endemic areas lower limb lesions were more common and upper limb lesions were less common in men than in women $[7,76]$. The most likely explanation for this differential pattern of lesion distribution is that women in Africa more commonly protect their lower limbs with clothing as compared to women in South America or Australia. Along the same line, men tend to be more often affected on the chest than women $[64,69]$. Similarly, differential exposure to M. ulcerans may serve as an explanation for differences between age groups. It was reported that in children below 5 years of age any part of the body may be affected, while with increasing age the head and the trunk seem to be less commonly affected and limb lesions become more dominant $[7,57,62,76]$. Failure to wear protective clothing has been identified as a risk factor for BU in several case-control studies [79-81]. In summary, the distribution of BU lesions appears to be strongly correlated with exposure of body parts to M. ulcerans, which may in turn be related to insect bites, skin injuries, or both.

\subsubsection{WHO Categories and Clinical Manifestations of BU}

M. ulcerans infections have been classified by WHO into three categories: category I is defined as a single, small lesion $<5 \mathrm{~cm}$ in diameter, category II includes single lesions between 5 and $15 \mathrm{~cm}$ in diameter, plaque and edematous forms, and 
category III is comprised of single extensive lesions $>15 \mathrm{~cm}$ in diameter, multiple lesions, lesions at critical sites (e.g. eye, genitalia, joints), and osteomyelitis [82]. There are marked differences in the proportion of BU patients presenting at health facilities with lesions of one of these categories for different geographical regions (Table 2). In Japan and Australia, where healthcare is readily available, the vast majority of BU patients present with category I lesions, for which standard national antibiotic regimens are highly effective. On the contrary, a significant proportion of BU patients in Africa and in particular those detected by active case search, present with more advanced stages of the disease, for which time required for healing is prolonged and healing is often accompanied by permanent disability. The percentage of patients with category II and III lesions is strongly dependent on the degree of remoteness of a population and consequently access to healthcare as well as with awareness of the disease among populations at risk. A high degree of awareness among the Rwandan population in the Kinyara refugee settlement as well as the establishment of a BU treatment center, has for example led to reporting at early stages of the disease [7]. On the contrary, due to a lack of adequate health infrastructure for the diagnosis and treatment of BU, a large cohort of patients from southwestern Nigeria presented to a health center in Benin with $58 \%$ category III and only $8 \%$ category I lesions [68]. Osteomyelitis is mainly observed in African populations $[61,63,68]$ and only occasionally in Australia [71]. The fact that ulcers are the most common form of BU lesions in all of the affected geographical areas is related to the relatively unspecific, nodular onset and the often reported painlessness [84] of M. ulcerans disease.

\subsection{Geographical Features of $\boldsymbol{M}$. ulcerans Infection Foci}

\subsubsection{Environmental and Climatic Characteristics of BU Endemic Areas}

Environmental and climatic factors are highly diverse in different $M$. ulcerans infection foci, not only if areas are compared where either the ancestral or the classical lineage prevails, but also among areas affected by the same lineage (Table 3).

French Guiana is located at the Atlantic Ocean in northern South America between Suriname and northern Brazil. Most of the inhabitants reside along a $50 \mathrm{~km}$ wide coastline, which is mainly composed of marshy savannah and mangroves, whereas the rest of the country consists of dense, barely accessible rainforest. Located between latitudes $2^{\circ}$ and $6^{\circ} \mathrm{N}$ and rising only to modest elevations, the climate in French Guiana is tropical (hot and humid) all year round. While rainfall may be heavy from January to June/July, the period between August and December is considered the main dry season [85]. The highest mean incidence of BU was detected in the western coastal area around the towns of Sinnamary and Mana adjacent to the Sinnamary and La Mana rivers, respectively [69]. On the contrary, Japan extends through a wide latitude from $30^{\circ}$ to $45^{\circ} \mathrm{N}$, with climate conditions ranging from humid subtropical to humid continental. BU cases are sporadically distributed throughout the large, mountainous Honshu Island, which separates the Sea of Japan 


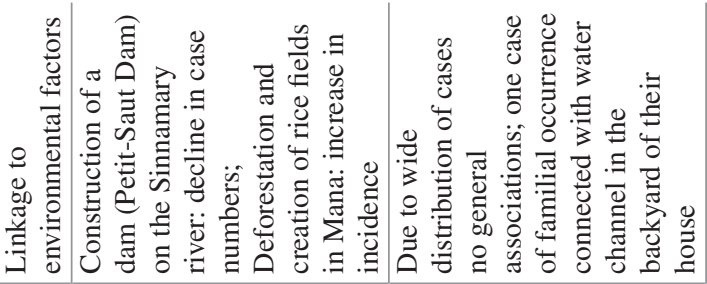

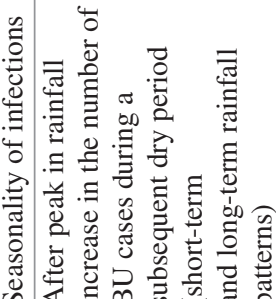

总入

需

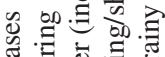

$\exists=$

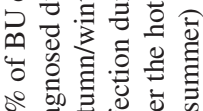

○̊ :

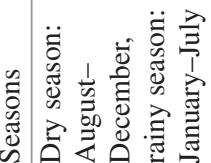

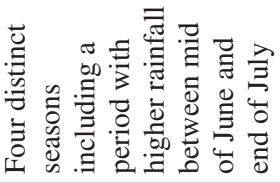

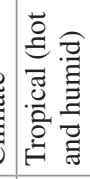

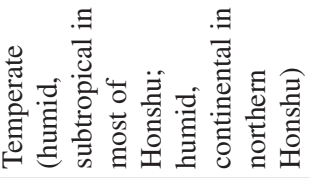

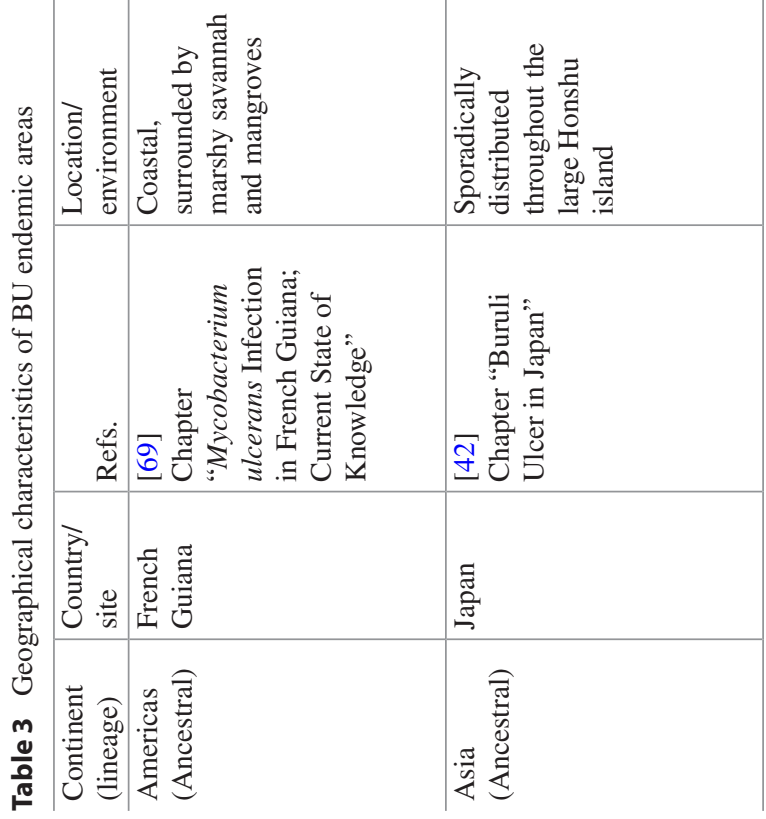




\begin{tabular}{|c|c|c|}
\hline 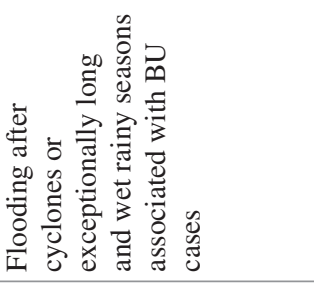 & 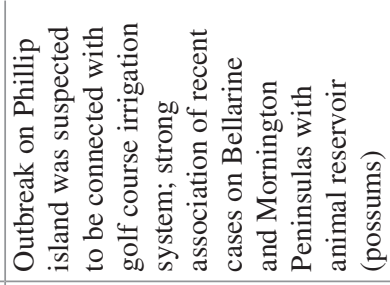 & 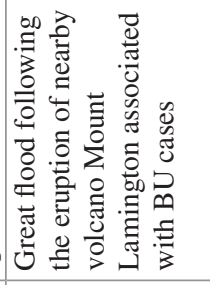 \\
\hline 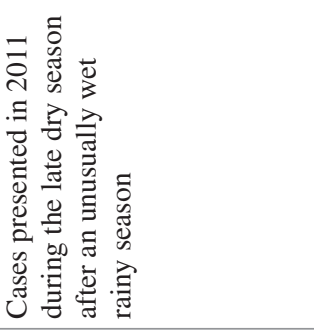 & 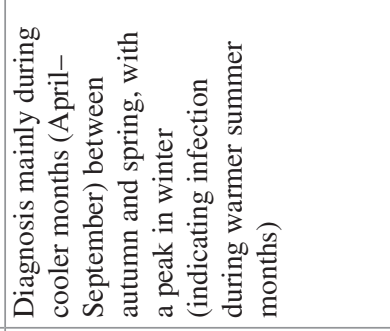 & 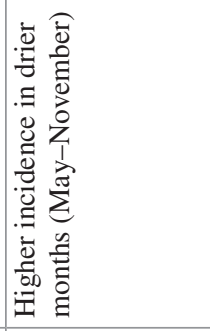 \\
\hline 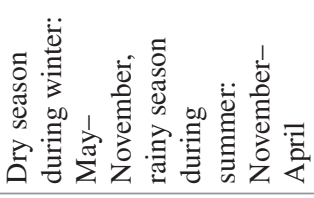 & 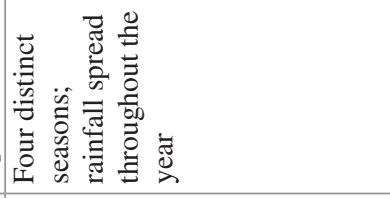 & 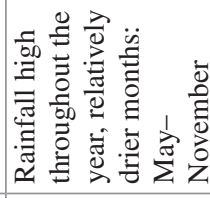 \\
\hline 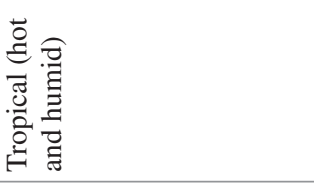 & 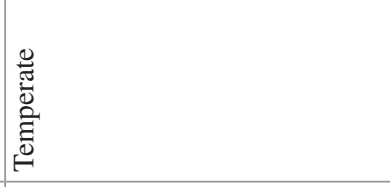 & 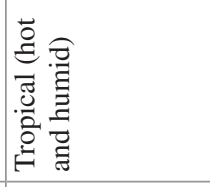 \\
\hline 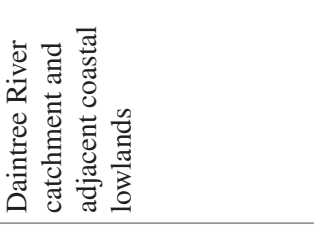 & 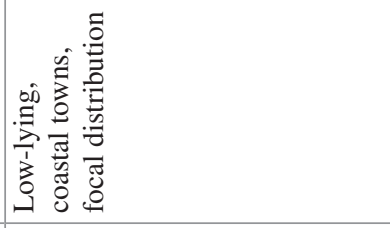 & 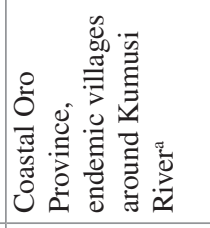 \\
\hline $\begin{array}{l}\stackrel{ }{2} \\
\mathbb{J}\end{array}$ & 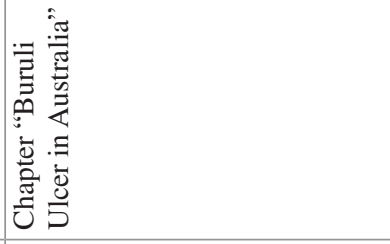 & $\bar{f}$ \\
\hline$\underset{z}{O}$ & 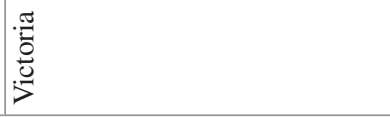 & U \\
\hline 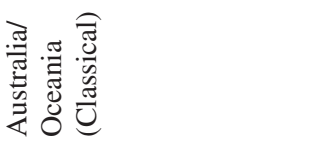 & & \\
\hline
\end{tabular}




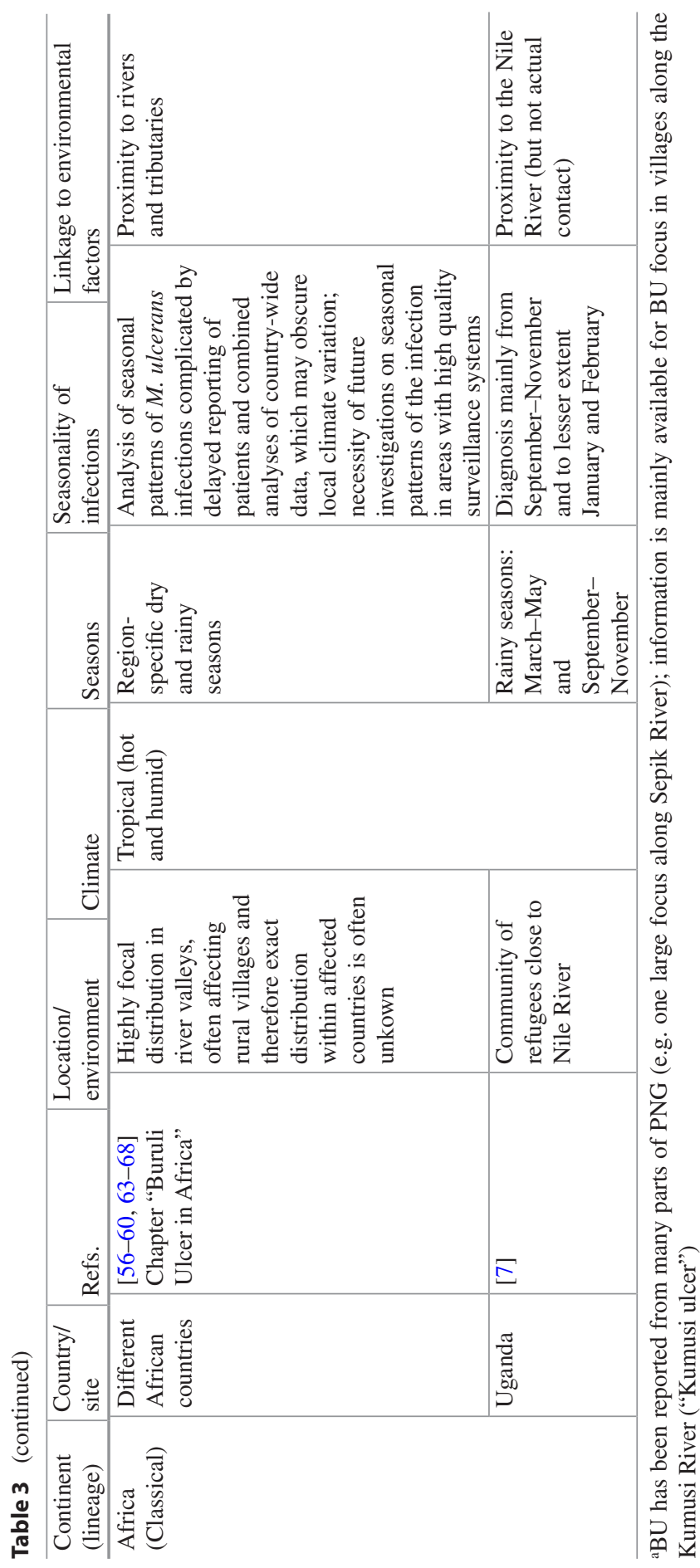


from the North Pacific Ocean. Much of Honshu belongs to the temperate zone with humid, subtropical climate characterized by four distinct seasons including a period with higher rainfall between mid of June and end of July. Humid, continental climate may be encountered in northern Honshu, with cold winters commonly experiencing snowfall [86]. The 60 sporadic BU cases reported between 2003 and 2016 in Japan were distributed over 17 of the 47 prefectures of the country (chapter "Buruli Ulcer in Japan" of this book). Interestingly, in some of the northern regions reporting BU cases, the temperature can be below zero degrees Celsius during the coldest season of the year. In Australia, M. ulcerans infections mainly occur in two geographically distinct areas in a temperate climatic zone in the south-eastern state of Victoria, and in tropical FNQ. In Victoria, M. ulcerans infections are consistently associated with low-lying coastal areas, where rainfall is spread throughout the year [75]. After first BU cases were described in the Bairnsdale region [2], the pathogen appeared to migrate westwards [87] causing larger outbreaks in the 1990s in Phillip Island [18] and Frankston/Langwarrin [17]. Since 1998 new foci have continuously appeared on the Bellarine and Mornington Peninsulas [71, 80, 88]. The second significant BU endemic area of Australia in FNQ comprises a rim of coastal valleys and lowlands surrounding the Dagmar Range, and extending from Daintree in the North to Mossman in the South [44]. The climate in FNQ is characterized by two distinct seasons with a warm, dry season during the winter period in May-October/ November and a warm, wet season during the summer period in November/ December-April [52]. Information on the distribution of BU in PNG is sparse, although infections have sporadically occurred in different parts of the country. One main BU focus was seen in the coastal Oro province in villages along the Kumusi River, where the climate is hot and humid and rainfall is high throughout the year with a relatively drier period from May to November [46]. BU endemic areas of West and Central Africa are mainly located in remote, rural areas and are characterized by a focal distribution with often high local prevalence rates. Affected regions have a tropical climate, typically with distinct dry and rainy seasons and are often associated with slow flowing and stagnant water bodies in proximity to large rivers. In West Africa the dry period lasts generally from November to February and is followed by region-specific rainy seasons. The southern areas of West Africa in the Guinea Coast region, where most of the BU cases occur, commonly experience two rainy seasons, one from April to July and a shorter one in September/October. In contrast, only one rainy period between July and September is observed in the North [89]. Distinct, region-specific dry and rainy seasons are also observed in Central African regions reporting BU cases [90].

Taken together M. ulcerans infection foci may be located in tropical or temperate climatic zones with or without distinct seasons, are connected with coastal lowlands in French Guiana, Australia and PNG, and with water bodies in remote, rural inland or coastal areas of Africa (Table 3).

\subsubsection{Seasonality of BU Transmission}

The detection and interpretation of seasonal fluctuations in the incidence of $M$. ulcerans disease is complicated by a combination of different factors, including 
the extremely long incubation period of the infection and the lack of knowledge on the mode of transmission and accordingly the timing of the infection, unless the patient has visited an endemic area only once and for a short time. Furthermore, features of early lesions are relatively uncharacteristic, causing delays in detection of the disease and reporting to health facilities. Well-documented records of BU cases among short-term visitors to BU endemic sites represent a unique source for the estimation of the time from exposure to disease onset. This approach was applied in south-eastern Australia by systematic identification of BU patients with a single visit exposure to one of the well-known focal BU endemic areas. The mean incubation period determined for patients infected in Victoria was 4.5 months with a wide variation from 32 to 264 days $[91,92]$. In the Daintree region of FNQ, a large spike of BU cases was observed in September and October 2011, 7-8 month after an exceptionally long and very wet rainy season with peak rainfall in February 2011 that was suspected to be connected with the occurrence of the infections [44]. While this may speak for a longer average incubation period in FNQ as compared to Victoria, in the Kinyara refugee camp in Uganda, the period between short stays of visitors and the development of BU was estimated to be between 1 and 3 months [7]. These apparent differences in the mean incubation period may be due to mode of transmission-related differences in the inoculation dose of $M$. ulcerans. All of these studies have shown that the time interval between exposure and onset of symptoms and finally to the diagnosis of BU can vary substantially on an individual basis, which may obscure potentially distinct seasonal variations in transmission intensity. Nevertheless, seasonal patterns of BU incidence have been reported for infection foci caused by both ancestral and classical M. ulcerans strains (Table 3). In French Guiana, M. ulcerans was found to be correlated with short-term (6 months) and long-term (a decade) rainfall patterns and the El Niño-Southern oscillation [85], (chapter "Mycobacterium ulcerans Infection in French Guiana; Current State of Knowledge" of this book). In Japan, approximately $80 \%$ of the reported BU cases were diagnosed during autumn and winter [42] (chapter "Buruli Ulcer in Japan" of this book), indicating contraction of the infection during or shortly after the hot and rainy season in summer. Between 2009 and 2015, most BU cases in FNQ were diagnosed during the dry season from July to November, which is likely explained by a surge in transmission during the wet season [44]. For the BU endemic focus in villages along the Kumusi River in PNG, a consistently higher incidence of cases in the drier months (May-November) was recorded [46].

Analyses of seasonal patterns of M. ulcerans infection are particularly difficult for remote BU endemic regions in Africa, where very long delays in reporting of patients to the public health system have to be taken into account. In addition, several studies assessing seasonal patterns of the disease in Africa have used country-wide data, ignoring local differences in rainfall patterns. In a study assessing seasonal patterns of BU in an endemic area of Cameroon, case incidences between 2002 and 2012 peaked in March. Assuming a delay between infection and diagnosis of 5-6 months, this suggested that the risk of infection is highest during the high rainy season from August to October [93]. 
Similarly, transmission in the Kinyara refugee camp, was estimated to be greatest from July to September [7].

Seasonal patterns of BU incidence may result from differences in the environmental presence of the pathogen or potential vectors, as well as from behaviourassociated variations in exposure of populations to $M$. ulcerans. These variations may be triggered by climatic conditions and connected landscape dynamics as well as by seasonal changes in agricultural and other activities intensifying environmental exposure. Considering the general association of BU endemicity with aquatic ecosystems, one of the main drivers of increased transmission may be flooding and the seasonal appearance of stagnant temporary water bodies and swamps, providing a breeding ground for potential reservoirs/vectors and/or the pathogen itself.

\subsubsection{Linkage of the Emergence of BU Foci to Environmental Changes}

Altered environmental conditions may be favourable for the growth and dissemination of pathogens and may lead to increased contact of populations to pathogens, i.e. their vector(s) and/or environmental reservoir(s) [94, 95]. Therefore changes in land use including intensification and changes in the nature of agricultural activities, water management projects, deforestation and urbanization as well as natural phenomena, such as cyclones, flooding, or volcanic eruption can lead to ecological edge effects that promote disease emergence. It is suspected, that the emergence of some of the M. ulcerans infection foci was related to different types of ecological and environmental disturbances (Table 3).

In French Guiana, an increase in the incidence of BU in Mana between 1984 and 1988 was observed just after the creation of rice fields [69]. On the other hand, construction of the hydroelectric Petit-Saut Dam on the Sinnamary River in 1994 upstream of an adjacent BU endemic area has been associated with a significant decline in case numbers, possibly due to a better regulation of water flows. In Japan, a BU outbreak affecting several members of a family was linked to a stagnant agricultural water channel [37] and in Victoria an outbreak in Phillip Island in the 1990s was suspected to be triggered by a newly formed lake and/or a golf course irrigation system [96]. The population in BU endemic areas along the Kumusi River in PNG has claimed that infections had only occurred after a great flood following the eruption of the nearby volcano Mount Lamington. In FNQ, a spike of cases seen in 2011 was connected with the aforementioned exceptionally long and very wet rainy season. The subsequent decrease in the number of cases since 2011, may be due to much drier conditions in the following years [44]. In African BU endemic areas associations have been suspected between BU incidence and damming of rivers or streams leading to the creation of artificial lakes; e.g. a small stream on the University campus in Ibadan, Nigeria [97], the Mapé River in Cameroon [98], the Densu River in Ghana, or the Bandama River in Côte d'Ivoire [99]. High risk zones for the contraction of BU were also connected with land cover changes; e.g. establishment of irrigated rice and banana fields in Côte d'Ivoire [100] or areas of mining and agricultural activity in Ghana [101]. 


\section{$4 \quad$ Risk/Protective Factors for BU}

In order to identify risk factors for BU, a number of case-control studies were conducted in areas endemic for the classical lineage of $M$. ulcerans. In view of a limited reliability of the clinical diagnosis, laboratory confirmation of patients enrolled in these studies is a crucial prerequisite for the quality of obtained results. Due to the multitude of studies conducted on behavioural risk factors for BU, only those with laboratory-confirmed patients were included here. On the other hand, considering that only very limited information is available to date on potential host genetic factors and on the impact of BCG vaccination and HIV co-infection, also studies with only partly reconfirmed cases are discussed in the corresponding paragraphs. The BU case confirmation status of all of these studies is listed in Table 4.

Table 4 Assessment of risk factors for the contraction of BU caused by classical M. ulcerans strains identified by comparative case-control studies

\begin{tabular}{|c|c|c|c|c|c|c|}
\hline $\begin{array}{l}\text { Country/ } \\
\text { site }\end{array}$ & $\begin{array}{l}\text { Time } \\
\text { span of } \\
\text { study } \\
\text { (Ref.) }\end{array}$ & $\begin{array}{l}\text { No of } \\
\text { confirmed }^{\text {a }} \\
\text { BU cases }\end{array}$ & $\begin{array}{l}\text { No of } \\
\text { controls } \\
\text { (matching } \\
\text { factors) }\end{array}$ & $\begin{array}{l}\text { Assessed risk } \\
\text { factors }\end{array}$ & $\begin{array}{l}\text { Risk factors } \\
\text { identified }\end{array}$ & $\begin{array}{l}\text { Protective } \\
\text { factors } \\
\text { identified }\end{array}$ \\
\hline \multicolumn{7}{|c|}{ Behavioural risk factors } \\
\hline $\begin{array}{l}\text { Australia } \\
\text { (Victoria) }\end{array}$ & $\begin{array}{l}1998- \\
2005 \\
{[80]}\end{array}$ & 49 & $\begin{array}{l}609 \\
\text { (community- } \\
\text { based) }\end{array}$ & $\begin{array}{l}\text { Lifestyle and } \\
\text { insect } \\
\text { exposure }\end{array}$ & $\begin{array}{l}\text { Mosquito } \\
\text { bites on } \\
\text { lower legs } \\
\text { and lower } \\
\text { arms }\end{array}$ & $\begin{array}{l}\text { Use of } \\
\text { insect } \\
\text { repellent, } \\
\text { wearing } \\
\text { protective } \\
\text { clothing, } \\
\text { washing } \\
\text { of wounds }\end{array}$ \\
\hline Benin & $\begin{array}{l}2006- \\
2008 \\
{[105]}\end{array}$ & 104 & $\begin{array}{l}312 \\
\text { (community- } \\
\text { based; } \\
\text { matched by } \\
\text { age, sex and } \\
\text { village of } \\
\text { residence) }\end{array}$ & $\begin{array}{l}\text { Water } \\
\text { sources, } \\
\text { family } \\
\text { relationships }\end{array}$ & $\begin{array}{l}\text { BU history } \\
\text { in the } \\
\text { family, } \\
\text { contact with } \\
\text { natural } \\
\text { water } \\
\text { sources }\end{array}$ & \\
\hline $\begin{array}{l}\text { Côte } \\
\text { d'Ivoire }\end{array}$ & $\begin{array}{l}2012 \\
{[102]}\end{array}$ & 51 & $\begin{array}{l}102 \text { (hospital/ } \\
\text { health } \\
\text { center-based; } \\
\text { matched by } \\
\text { age } \\
\text { ( } \pm 5 \text { years), } \\
\text { sex, and type } \\
\text { of residency) }\end{array}$ & $\begin{array}{l}\text { Socio- } \\
\text { sanitary, } \\
\text { environment, } \\
\text { and behaviour }\end{array}$ & $\begin{array}{l}\text { Regular } \\
\text { contact with } \\
\text { unprotected } \\
\text { surface } \\
\text { water and } \\
\text { absence of } \\
\text { protective } \\
\text { equipment } \\
\text { during } \\
\text { agricultural } \\
\text { activities }\end{array}$ & $\begin{array}{l}\text { Good } \\
\text { knowledge } \\
\text { about the } \\
\text { risks that } \\
\text { may result } \\
\text { in BU and } \\
\text { perception } \\
\text { about the } \\
\text { disease } \\
\text { causes }\end{array}$ \\
\hline
\end{tabular}


Table 4 (continued)

\begin{tabular}{|c|c|c|c|c|c|c|}
\hline $\begin{array}{l}\text { Country/ } \\
\text { site }\end{array}$ & $\begin{array}{l}\text { Time } \\
\text { span of } \\
\text { study } \\
\text { (Ref.) }\end{array}$ & $\begin{array}{l}\text { No of } \\
\text { confirmed }^{a} \\
\text { BU cases }\end{array}$ & $\begin{array}{l}\text { No of } \\
\text { controls } \\
\text { (matching } \\
\text { factors) }\end{array}$ & $\begin{array}{l}\text { Assessed risk } \\
\text { factors }\end{array}$ & $\begin{array}{l}\text { Risk factors } \\
\text { identified }\end{array}$ & $\begin{array}{l}\text { Protective } \\
\text { factors } \\
\text { identified }\end{array}$ \\
\hline \multirow[t]{4}{*}{ Ghana } & $\begin{array}{l}1999 \\
{[104]}\end{array}$ & 51 & $\begin{array}{l}51 \text { (hospital- } \\
\text { based; } \\
\text { matched by } \\
\text { age group, } \\
\text { sex, BCG) }\end{array}$ & Water-related & $\begin{array}{l}\text { Swimming } \\
\text { in rivers on } \\
\text { a habitual } \\
\text { basis }\end{array}$ & \\
\hline & $\begin{array}{l}2000 \\
{[79]}\end{array}$ & 116 & $\begin{array}{l}116 \\
\text { (community- } \\
\text { based; } \\
\text { matched by } \\
\text { age and } \\
\text { village) }\end{array}$ & $\begin{array}{l}\text { Environment } \\
\text { and behavior }\end{array}$ & $\begin{array}{l}\text { Wading in a } \\
\text { river or } \\
\text { stream }\end{array}$ & $\begin{array}{l}\text { Wearing a } \\
\text { shirt while } \\
\text { farming, } \\
\text { sharing } \\
\text { indoor } \\
\text { living } \\
\text { space with } \\
\text { livestock, } \\
\text { bathing } \\
\text { with toilet } \\
\text { soap }\end{array}$ \\
\hline & $\begin{array}{l}2010- \\
2011 \\
{[81]}\end{array}$ & 113 & $\begin{array}{l}113 \\
\text { (community- } \\
\text { based; } \\
\text { matched by } \\
\text { age, sex and } \\
\text { village) }\end{array}$ & $\begin{array}{l}\text { Demography, } \\
\text { socio- } \\
\text { economy, } \\
\text { health and } \\
\text { hygiene as } \\
\text { well as } \\
\text { environment }\end{array}$ & $\begin{array}{l}\text { Presence of } \\
\text { wetland, } \\
\text { insect bites } \\
\text { in water, use } \\
\text { of adhesive } \\
\text { when } \\
\text { injured, and } \\
\text { washing in } \\
\text { river }\end{array}$ & $\begin{array}{l}\text { Use of } \\
\text { alcohol } \\
\text { for } \\
\text { injuries, } \\
\text { covering } \\
\text { limbs } \\
\text { during } \\
\text { farming }\end{array}$ \\
\hline & $\begin{array}{l}2013- \\
2015 \\
{[103]}\end{array}$ & 176 & $\begin{array}{l}176 \\
\text { (community- } \\
\text { based; } \\
\text { matched by } \\
\text { age } \\
\text { ( } \pm 5 \text { years), } \\
\text { sex, and place } \\
\text { of residence) }\end{array}$ & $\begin{array}{l}\text { Demography, } \\
\text { environment, } \\
\text { and behaviour }\end{array}$ & $\begin{array}{l}\text { Farming in } \\
\text { swampy } \\
\text { areas, } \\
\text { farming } \\
\text { while } \\
\text { wearing } \\
\text { short } \\
\text { clothing, } \\
\text { insect bites, } \\
\text { and } \\
\text { application } \\
\text { of leaves on } \\
\text { wounds }\end{array}$ & $\begin{array}{l}\text { Farming in } \\
\text { long } \\
\text { clothing, } \\
\text { washing } \\
\text { wounds } \\
\text { with water, } \\
\text { and } \\
\text { application } \\
\text { of adhesive } \\
\text { bandage on } \\
\text { wounds }\end{array}$ \\
\hline
\end{tabular}


Table 4 (continued)

\begin{tabular}{|c|c|c|c|c|c|c|}
\hline $\begin{array}{l}\text { Country/ } \\
\text { site }\end{array}$ & $\begin{array}{l}\text { Time } \\
\text { span of } \\
\text { study } \\
\text { (Ref.) }\end{array}$ & $\begin{array}{l}\text { No of } \\
\text { confirmed }^{\text {a }} \\
\text { BU cases }\end{array}$ & $\begin{array}{l}\text { No of } \\
\text { controls } \\
\text { (matching } \\
\text { factors) }\end{array}$ & $\begin{array}{l}\text { Assessed risk } \\
\text { factors }\end{array}$ & $\begin{array}{l}\text { Risk factors } \\
\text { identified }\end{array}$ & $\begin{array}{l}\text { Protective } \\
\text { factors } \\
\text { identified }\end{array}$ \\
\hline Togo & $\begin{array}{l}2014- \\
2015 \\
{[106]}\end{array}$ & 83 & $\begin{array}{l}128 \\
\text { (community- } \\
\text { based; } \\
\text { matched by } \\
\text { sex and place } \\
\text { of residence) }\end{array}$ & $\begin{array}{l}\text { Socio- } \\
\text { demography, } \\
\text { environment } \\
\text { and behaviour }\end{array}$ & $\begin{array}{l}\text { Bathing with } \\
\text { water from } \\
\text { open } \\
\text { borehole, } \\
\text { frequently } \\
\text { crossing or } \\
\text { swimming } \\
\text { in a river, } \\
\text { and } \\
\text { receiving } \\
\text { cuts, } \\
\text { scratches or } \\
\text { insect bites } \\
\text { near a river }\end{array}$ & $\begin{array}{l}\text { Using } \\
\text { detergents } \\
\text { for } \\
\text { washing } \\
\text { clothes or } \\
\text { dishes }\end{array}$ \\
\hline \multicolumn{7}{|c|}{ Host genetic factors } \\
\hline Benin & $\begin{array}{l}2005- \\
2013 \\
{[111]}\end{array}$ & 208 & $\begin{array}{l}300 \\
\text { (community- } \\
\text { based; } \\
\text { matched by } \\
\text { age, sex, } \\
\text { water contact } \\
\text { habits, and } \\
\text { ethnic } \\
\text { background) }\end{array}$ & $\begin{array}{l}\text { Autophagy- } \\
\text { related genes }\end{array}$ & $\begin{array}{l}\text { rs } 1333955 \\
\text { SNP in } \\
\text { PARK2 }\end{array}$ & $\begin{array}{l}\text { rs2241880 } \\
\text { SNP in } \\
\text { ATG16L1 }\end{array}$ \\
\hline \multirow[t]{2}{*}{ Ghana } & $\begin{array}{l}2006 \\
{[110]}\end{array}$ & 102 of 182 & $\begin{array}{l}191 \\
\text { (community- } \\
\text { based; } \\
\text { matched by } \\
\text { age) }\end{array}$ & $\begin{array}{l}\text { Polymorphisms } \\
\text { in the natural } \\
\text { resistance- } \\
\text { associated } \\
\text { macrophage } \\
\text { protein gene } \\
\text { (SLC11A1) }\end{array}$ & $\begin{array}{l}\text { D543N in } \\
\text { SLC11A1 }\end{array}$ & \\
\hline & $\begin{array}{l}2011 \\
{[109]}\end{array}$ & 96 & $\begin{array}{l}384 \\
\text { (community- } \\
\text { based; } \\
\text { matched by } \\
\text { age, sex, } \\
\text { ethnicity and } \\
\text { home village) }\end{array}$ & $\begin{array}{l}\text { Polymorphisms } \\
\text { in genes known } \\
\text { to be associated } \\
\text { with } \\
\text { susceptibility to } \\
\text { Tuberculosis } \\
\text { and Leprosy }\end{array}$ & $\begin{array}{l}\text { rs9282799 } \\
\text { SNP in iNOS } \\
\text { and } \\
\text { rs2069705 in } \\
\text { IFNG }\end{array}$ & \\
\hline
\end{tabular}


Table 4 (continued)

\begin{tabular}{|c|c|c|c|c|c|c|}
\hline $\begin{array}{l}\text { Country/ } \\
\text { site }\end{array}$ & $\begin{array}{l}\text { Time } \\
\text { span of } \\
\text { study } \\
\text { (Ref.) }\end{array}$ & $\begin{array}{l}\text { No of } \\
\text { confirmed }^{\text {a }} \\
\text { BU cases }\end{array}$ & $\begin{array}{l}\text { No of } \\
\text { controls } \\
\text { (matching } \\
\text { factors) }\end{array}$ & $\begin{array}{l}\text { Assessed risk } \\
\text { factors }\end{array}$ & $\begin{array}{l}\text { Risk factors } \\
\text { identified }\end{array}$ & $\begin{array}{l}\text { Protective } \\
\text { factors } \\
\text { identified }\end{array}$ \\
\hline \multicolumn{7}{|c|}{$B C G$ vaccination } \\
\hline Benin & $\begin{array}{l}2002- \\
2003 \\
{[117]}\end{array}$ & 134 of 279 & $\begin{array}{l}988 \\
\text { (community- } \\
\text { based; } \\
\text { matched by } \\
\text { age and sex) }\end{array}$ & $\begin{array}{l}\text { BCG } \\
\text { vaccination }\end{array}$ & None & None \\
\hline $\begin{array}{l}\text { Côte } \\
\text { d'Ivoire }\end{array}$ & $\begin{array}{l}2001 \\
{[119]}\end{array}$ & 56 of 116 & $\begin{array}{l}116 \\
\text { (community- } \\
\text { based; } \\
\text { matched by } \\
\text { age, sex, and } \\
\text { village) }\end{array}$ & $\begin{array}{l}\text { BCG } \\
\text { vaccination } \\
\text { (and other } \\
\text { risk factors } \\
\text { not discussed } \\
\text { here) }\end{array}$ & $\begin{array}{l}\text { No history } \\
\text { of BCG } \\
\text { vaccination }\end{array}$ & \\
\hline $\begin{array}{l}\text { DRC, } \\
\text { Ghana } \\
\text { and Togo }\end{array}$ & $\begin{array}{l}2010- \\
2013 \\
{[118]}\end{array}$ & 401 & $\begin{array}{l}826 \text { (mostly } \\
\text { family } \\
\text { members and } \\
\text { neighbours) }\end{array}$ & $\begin{array}{l}\text { BCG } \\
\text { vaccination }\end{array}$ & None & None \\
\hline Ghana & $\begin{array}{l}2000 \\
{[79]}\end{array}$ & 116 & $\begin{array}{l}116 \\
\text { (community- } \\
\text { based; } \\
\text { matched by } \\
\text { age and } \\
\text { village) }\end{array}$ & $\begin{array}{l}\text { BCG } \\
\text { vaccination } \\
\text { (and other } \\
\text { risk factors } \\
\text { discussed } \\
\text { above) }\end{array}$ & None & None \\
\hline \multicolumn{7}{|c|}{ HIV co-infection } \\
\hline Benin & $\begin{array}{l}2002- \\
2003 \\
{[120]}\end{array}$ & 258 of 426 & $\begin{array}{l}613 \\
\text { (community) }\end{array}$ & HIV infection & $\begin{array}{l}\text { HIV } \\
\text { infection }\end{array}$ & \\
\hline Ghana & $\begin{array}{l}2000 \\
{[79]}\end{array}$ & 116 & $\begin{array}{l}116 \\
\text { (community- } \\
\text { based; } \\
\text { matched by } \\
\text { age and } \\
\text { village) }\end{array}$ & $\begin{array}{l}\text { HIV infection } \\
\text { (and other } \\
\text { risk factors } \\
\text { discussed } \\
\text { above) }\end{array}$ & None & None \\
\hline
\end{tabular}

${ }^{a}$ Laboratory confirmation of clinically diagnosed patients by at least one diagnostic test

\subsection{Behavioural Risk Factors}

Failure to wear protective clothing $[102,103]$ and activities close to or in certain unprotected water sources $[79,81,102-106]$ have repeatedly been connected with an increased risk of contracting BU. Conversely, wearing protective clothing [79$81,103]$, wound care $[80,81,103]$ and good hygiene $[79,106]$ have been identified 
as factors conferring some degree of protection (Table 4). In southeastern Australia, where an involvement of mosquitoes in the transmission of M. ulcerans infections as either biological or purely mechanical vectors of the pathogen has been suggested, mosquito bites were identified as a risk factor. In addition to using insect repellent, immediate cleansing of wounds has also been associated with a decreased risk of contracting an $M$. ulcerans infection [80]. In African settings, insect bites, but also cuts and scratches near or in water bodies have been linked with an increased risk of infection [106]. One of the case-control studies came to the conclusion that good knowledge about BU and the risk factors involved in infection had a protective effect [102].

\subsection{Host Genetic Factors}

With the availability of a large number of human genome sequences, millions of polymorphic markers have been identified [107]. For case-control studies aiming at uncovering genetic factors that influence disease susceptibility, there are two main principal approaches; one based on testing candidate genes and the other based on genome-wide association studies. While candidate gene studies have higher statistical power, they cannot discover new markers or marker combinations. Even with several thousands of samples, genome-wide association studies can on the other hand be underpowered [108] and in the case of infectious diseases the element of exposure adds complexity and can contribute to statistical noise.

In view of the limited number of BU patients that can be enrolled for geographically restricted case-control studies, it is not surprising that only candidate gene studies have so far been conducted for BU. To date, single nucleotide polymorphisms (SNPs) in the inducible nitric oxide synthase gene iNOS and in the interferon gamma gene IFNG [109], the natural resistance-associated macrophage protein gene SLC11A1 (NRAMP1) [110], and the autophagy-related E3 ubiquitinprotein ligase gene PARK2 [111] have been linked to susceptibility to BU (Table 4). However, these initial findings should be reconfirmed in future studies enrolling larger BU patient cohorts.

The fact that SNPs, which reduce the promoter activity of $i N O S$ and IFNG implicated in macrophage activation, were found to increase susceptibility to BU, support the hypothesis that macrophages may be of crucial importance for the containment of M. ulcerans infections. Also, the influence of polymorphisms in SLC11A1 implicated in the transport of divalent cations to late endosomes/lysosomes [112] and in the ubiquitin ligase PARK2 implicated in resistance to intracellular pathogens [113], hint to a key role of macrophages in the early stage of an $M$. ulcerans infection, when low mycolactone levels may still permit elimination of the inoculated mycobacteria. For more detailed information on the immunology of BU the reader is referred to chapter "The Immunology of Buruli Ulcer" of this book. It should be noted however, that selection of candidate genes investigated so far was strongly biased towards host polymorphisms that have previously shown significant associations with susceptibility to intracellular mycobacteria, such as $M$. 
tuberculosis and M. leprae. Genome-wide association studies for susceptibility to BU could thus potentially reveal even more robust gene-disease association data for genes that are relevant for other immune effector mechanisms.

\subsection{BCG Vaccination}

No specific vaccine is currently available to prevent $M$. ulcerans disease, but the protective effectiveness of Mycobacterium bovis Bacillus Calmette-Guérin (BCG) vaccination has been controversially discussed [114]. Two randomized controlled trials, one at the settlement of Rwandan refugees in Kinyara between 1967 and 1969 [115] and a second in another BU endemic area of Uganda in the 1970s [116] indicated a certain protective effect of BCG vaccination, although protection appeared to be short-lived [116]. Results of three case-control studies showed no evidence of a protective effect of BCG vaccination on the risk of developing BU $[79,117,118]$, whereas no history of BCG vaccination appeared to be associated with BU in another study [119] (Table 4). Uncertainty about the BCG vaccination status among study populations with missing vaccination records should be considered as a potential confounder in these investigations.

\subsection{BU-HIV Co-infection}

BU-HIV co-infection is not uncommon due to the high HIV prevalence in many BU endemic areas. But until today, there is paucity of information on epidemiological and clinical relationships of the two infections. A case-control study conducted in Benin found that the prevalence of HIV in BU patients $(2.6 \%)$ was significantly higher $(\mathrm{P}=0.003)$ than that of the local control population $(0.3 \%)$ [120], indicating that HIV increases the risk of BU. Similar percentages were reported in another case-control study performed in Ghana, with $5 \%$ of the BU patients and $0.9 \%$ of the control individuals testing positive for HIV, although - probably due to the small number of study participants - this association was not statistically significant [79] (Table 4). Furthermore, the prevalence of HIV among BU patients was significantly higher than that of the regional estimated prevalence [121] or that of other patients or pregnant women attending the same health facilities [122]. HIV infection weakens the immune system and seems to also affect the clinical presentation of BU, as co-infected patients tend to have more severe and more often multifocal lesions than HIV-negative patients [121, 122]. This is also indicated by a number of BU-HIV case reports describing aggressive, multifocal BU disease progression [123-128]. Management of BU-HIV co-infection is challenging [129]. It is recommended that all BU patients should be tested for HIV co-infection and that HIV-positive individuals should receive early antiretroviral treatment to reduce mortality (for more information on the management of BU-HIV co-infection see chapter "Management of BU-HIV Co-infection" of this book), which seems to be higher in BU-HIV coinfected than in HIV-negative patients [121, 122, 126, 128]. 


\section{$5 \quad$ Diagnosis and Treatment of BU in Different Geographical Settings}

The diagnosis of $M$. ulcerans infections is not trivial. The disease has a wide spectrum of clinical manifestations including ulcerative lesions as well as non-ulcerative forms such as nodules, plaques, and edema. As a consequence, the differential diagnosis of BU is broad, particularly in tropical endemic areas, where the prevalence of skin conditions with similar presentations is high [130]. Findings from a recent retrospective assessment of the diagnosis of BU in Ghana between 2008 and 2016 has revealed that in over $50 \%$ of all cases, a clinical suspicion of BU could not be confirmed by laboratory testing [59]. While surgical excision of lesions had long been the only treatment option for BU, pre-treatment laboratory confirmation of $M$. ulcerans infections has gained further in importance after the introduction of antibiotic therapy in 2004. In recent years, PCR targeting the IS2404 element of $M$. ulcerans has become a gold standard for the diagnosis of BU in reference laboratories of the endemic countries. PCR-based laboratory confirmation of suspected BU cases is routinely performed in countries with resource rich healthcare systems and good laboratory infrastructure such as Japan [131] and Australia [132]. In French Guiana, the proportion of laboratory-confirmed BU cases increased from $52 \%$ before PCR became available in 2000 to $92 \%$ after 2000 [69]. However, the main drawback of PCR-based diagnosis for rural African endemic areas is its limited accessibility. To date, the only laboratory test locally available is microscopy of Ziehl-Neelsen stained smears from lesion specimens, a method with low sensitivity. In-country PCR reconfirmation in Africa can only be performed at a few reference laboratories. Samples are often stored for bulk shipments to these laboratories, leading to delayed delivery of results. Initiation of antibiotic therapy is thus often based on clinical diagnosis only, bearing the risk that some of the BU patients (and also misdiagnosed non-BU patients) do not receive appropriate treatment. A low-tech, accurate, rapid diagnostic test for the diagnosis of BU is of urgent need. For more information on the laboratory diagnosis of BU see chapter "Laboratory Diagnosis of Buruli Ulcer: Challenges and Future Perspectives" of this book.

WHO treatment recommendations include an eight-week course of a rifampicinbased combination of antibiotics, and-if needed-adjunct debridement and skin grafting. Until recently, rifampicin-the most effective drug against $M$. ulceranswas prescribed in combination with intramuscular doses of streptomycin. However, administration of streptomycin through injections has a major impact on patient acceptance and adherence, and is often not practical in rural BU endemic areas. Moreover, prolonged use of streptomycin has been shown to cause permanent ototoxicity and transient nephrotoxicity in BU patients [133]. Therefore, the WHO Technical Advisory Group on Buruli ulcer recommended in 2017 to replace streptomycin with oral clarithromycin for BU treatment. Current first-line eight-week treatment regimens include rifampicin combined with clarithromycin, moxifloxacin or ciprofloxacin in Australia [134], a triple combination of rifampicin, levofloxacin, and clarithromycin in Japan (chapter "Buruli Ulcer in Japan" of this book) and 
rifampicin combined with amikacin or clarithromycin in French Guiana (chapter "Mycobacterium ulcerans Infection in French Guiana; Current State of Knowledge" of this book). WHO has developed a policy of free supplies of antibiotics to the affected countries on request from national BU control programs, which should in turn ensure that BU treatment facilities have an uninterrupted supply of the antibiotics [82]. However, the logistics involved in the provision of medication to remote, rural health facilities is challenging and hence antibiotics are not always available to patients in these areas. Alternative options for the treatment of BU, in particular the potential of new tuberculosis drug candidates are currently being investigated. Furthermore, local thermotherapy at the site of the lesions with simple phase change material devices showed promising results in a phase II clinical trial [135] and may be suitable for treatment at community level. For more information on the treatment of BU see chapters "Antimicrobial Treatment of Mycobacterium ulcerans Infection" and "Thermotherapy of Buruli Ulcer" of this book. Another important component to improve the healing process of lesions and to prevent secondary infections is adequate wound management. Interested readers are referred to chapter "Secondary Infection of Buruli Ulcer Lesions" of this book dealing with secondary infection and management of BU lesions.

\section{Socio-Economic Burden of BU for Patients and their Families}

The diagnosis and treatment of BU patients in Australia, Japan, and French Guiana is secured by well-resourced universal healthcare systems. In contrast, health services in remote $\mathrm{BU}$ endemic communities of Africa and PNG are often very limited. Although in many BU endemic countries, antibiotic treatment of BU is free of charge, other expenditures and required efforts may prevent patients from seeking care at the formal health system. The economic burden arising from transport, accommodation and food for patients and caregivers, lost earnings and work force may be too high for the affected families $[136,137]$, in particular if long hospital stays are required. Cultural beliefs, perceptions regarding the effectiveness of BU treatment, and stigma derived from the perceived mystical origin of the disease further aggravate the situation [138, 139] (see chapter "Social Science Contributions to BU Focused Health Service Research in West-Africa" of this book for more information on social science aspects of BU). In many BU endemic areas, patients prefer to first consult traditional healers and only refer to hospitals as a last resort [137]. Although BU is a slowly progressing disease, delays in receiving adequate medical care is detrimental to the treatment outcome. Chemotherapy is highly effective for early stages of BU, whereas the management of advanced stages is often complicated by delayed wound healing requiring prolonged hospitalization. Moreover, treatment of advanced BU may not prevent permanent functional disabilities.

Neglected tropical diseases (NTDs) have a substantial, cumulative effect on the economy and the health of affected populations, imposing a devastating social and 
economic burden on affected individuals, households and communities. A number of studies in BU endemic African countries have revealed that BU can push households into poverty, whether patients were hospitalized or not. For instance, the median cost burden of hospitalization of BU patients in Central Cameroon was reported to correspond to $25 \%$ of the annual earnings of a household due to high non-medical costs and productivity loss. More than half of the families were forced to withdraw financial and hence social support to the patient, resulting in the patient's isolation at the hospital. Indeed, social isolation of in-patients has been mentioned as the principal cause for abandonment of biomedical treatment [140]. On the other hand, for non-hospitalized BU patients in Ghana, transportation and other costs added up to $45 \%$ of the annual income of households. For these outpatients, social isolation was also an issue, particularly for children, who were often not accompanied for treatment [141]. In a study conducted in Nigeria it was revealed that costs before a definite diagnosis of BU was established (including costs for medications, drugs, wound care, hospitalization, transportation, food, and others), accounted for the brunt of the total costs for the treatment of BU. Costs were catastrophic for $50 \%$ of all affected households [142].

Taken together, new, socially more compatible intervention strategies, such as a more decentralized system of diagnosis and care as well as improved community mobilization and education of populations concerning BU to reduce care-seeking delays are of urgent need. Results of a recent pilot BU outreach campaign and decentralized care program in one of the most endemic districts of Benin demonstrated the great value of such interventions, reflected by a strong community support and a dramatic increase in the detection of BU cases that was associated with immediate, free, and accessible care [143]. However, a major challenge will be the mobilization of both financial and human (organization, training, health staff etc.) resources to implement and sustain decentralized care at a larger scale and on a long-term basis.

\section{$7 \quad$ Outlook}

Launching of the Global BU Initiative in 1998 and adding BU to the WHO list of NTDs, has helped to increase awareness of the disease among affected populations, health staff, potential donors, and researchers. As a result, national BU control programs were established in the affected countries, healthcare provision to BU patients was improved, and new diagnostic tools and treatment modalities have been developed. The decline in the number of new infections reported to WHO in the past years might on the one hand be a result of the progress made in the fight against the disease. Active case finding and treatment of patients with chronic ulcerative BU lesions, which may represent significant reservoirs of the pathogen, may be an important corner stone for the control of the disease. But on the other hand, the declining number of reported BU patients has also led to a decrease in awareness of and interest in the disease. The reduction in the number of reported cases may therefore be in part related to a decline in active case search activities in 
known BU endemic regions and also to a lack of efforts to identify new BU endemic areas. The large BU burden in Nigeria only became apparent when Nigerian patients presented to established BU health facilities in Benin [68, 144], indicating that the true number of BU cases in regions where no fully functional BU control programs are in place, may be vastly underestimated. While the detection and treatment of BU in Australia, Japan, and French Guiana will continue to be covered by their universal healthcare systems, a major task for the next years will be the sustained control of BU in Africa. For that purpose, funding for control activities and research has to be mobilized to maintain established healthcare infrastructure in the affected countries and to implement newly developed diagnostic tests and treatment regimens. Support by NGOs has played in many settings an important role in the development of BU control activities and treatment centers and was crucial for BU research funding (an example for funding of a BU research consortium by an NGO is provided in Chapter "Transdisciplinary Research and Action to Stop Buruli Ulcer: A Case Study from Philanthropy”). This has major implications for sustainability as reductions in program support by major partners may lead to severe drops in performance of BU control activities [145] and a loss in research output and capacity development.

Fragmentation of health interventions and services is a widely discussed issue, since narrowly targeted interventions can generate in particular in low resource settings inequity and substantial extra costs. Therefore, it has been suggested to integrate BU control into the broader context of care for skin NTDs [146]. The co-endemicity of several of these diseases, such as BU, yaws, scabies, mycetoma, and leprosy may allow maximizing financial and human resources by the implementation of integrated approaches, including training of health workers in differential diagnosis of skin NTDs, basic dermatology and wound management [147].

\section{References}

1. Cook A (1897) The Mengo hospital notes. Makere College Medical School Library, Kampala

2. MacCallum P, Tolhurst JC et al (1948) A new mycobacterial infection in man. J Pathol Bacteriol 60(1):93-122

3. Parson W (1999) Mycobacterium ulcerans. Lancet 354(9196):2171

4. Janssens PG, Quertinmont MJ, Sieniawski J, Gatti F (1959) Necrotic tropical ulcers and mycobacterial causative agents. Trop Geogr Med 11:293-312

5. Clancey JK, Dodge OG, Lunn HF, Oduori ML (1961) Mycobacterial skin ulcers in Uganda. Lancet 2(7209):951-954

6. Lunn HF, Connor DH, Wilks NE, Barnley GR, Kamunvi F, Clancey JK et al (1965) Buruli (Mycobacterial) ulceration in Uganda. (a new focus of Buruli ulcer in Madi District, Uganda): report of a field study. East Afr Med J 42:275-288

7. The Uganda Buruli Group (1971) Epidemiology of Mycobacterium ulcerans infection (Buruli ulcer) at Kinyara, Uganda. Trans R Soc Trop Med Hyg 65(6):763-775

8. The Uganda Buruli Group (1970) Clinical features and treatment of pre-ulcerative Buruli lesions (Mycobacterium ulcerans infection). Report II of the Uganda Buruli group. Br Med J 2(5706):390-393

9. Smith JH (1970) Epidemiologic observations on cases of Buruli ulcer seen in a hospital in the lower Congo. Am J Trop Med Hyg. 19(4):657-663 
10. Oluwasanmi JO, Solankee TF, Olurin EO, Itayemi SO, Alabi GO, Lucas AO (1976) Mycobacterium ulcerans (Buruli) skin ulceration in Nigeria. Am J Trop Med Hyg 25(1):122-128

11. Burchard GD, Bierther M (1986) Buruli ulcer: clinical pathological study of 23 patients in Lambarene, Gabon. Trop Med Parasitol 37(1):1-8

12. van der Werf TS, van der Graaf WT, Groothuis DG, Knell AJ (1989) Mycobacterium ulcerans infection in Ashanti region, Ghana. Trans R Soc Trop Med Hyg 83(3):410-413

13. Amofah GK, Sagoe-Moses C, Adjei-Acquah C, Frimpong EH (1993) Epidemiology of Buruli ulcer in Amansie west district, Ghana. Trans R Soc Trop Med Hyg 87(6):644-645

14. Muelder K, Nourou A (1990) Buruli ulcer in Benin. Lancet 336(8723):1109-1111

15. Darie H, Le Guyadec T, Touze JE (1993) Epidemiological and clinical aspects of Buruli ulcer in Ivory Coast. 124 recent cases. Bull Soc Pathol Exot 86(4):272-276

16. Marston BJ, Diallo MO, Horsburgh CR Jr, Diomande I, Saki MZ, Kanga JM et al (1995) Emergence of Buruli ulcer disease in the Daloa region of cote d'Ivoire. Am J Trop Med Hyg 52(3):219-224

17. Johnson PD, Veitch MG, Leslie DE, Flood PE, Hayman JA (1996) The emergence of Mycobacterium ulcerans infection near Melbourne. Med J Aust 164(2):76-78

18. Veitch MG, Johnson PD, Flood PE, Leslie DE, Street AC, Hayman JA (1997) A large localized outbreak of Mycobacterium ulcerans infection on a temperate southern Australian island. Epidemiol Infect 119(3):313-318

19. Igo JD, Murthy DP (1988) Mycobacterium ulcerans infections in Papua New Guinea: correlation of clinical, histological, and microbiologic features. Am J Trop Med Hyg. 38(2):391-392

20. Röltgen K, Pluschke G (2015) Epidemiology and disease burden of Buruli ulcer: a review. Res Rep Trop Med 2015(6):59-73

21. Stinear TP, Seemann T, Pidot S, Frigui W, Reysset G, Garnier T et al (2007) Reductive evolution and niche adaptation inferred from the genome of Mycobacterium ulcerans, the causative agent of Buruli ulcer. Genome Res 17(2):192-200

22. Qi W, Kaser M, Roltgen K, Yeboah-Manu D, Pluschke G (2009) Genomic diversity and evolution of Mycobacterium ulcerans revealed by next-generation sequencing. PLoS Pathog 5(9):e1000580

23. Mve-Obiang A, Lee RE, Portaels F, Small PL (2003) Heterogeneity of mycolactones produced by clinical isolates of Mycobacterium ulcerans: implications for virulence. Infect Immun 71(2):774-783

24. Mve-Obiang A, Lee RE, Umstot ES, Trott KA, Grammer TC, Parker JM et al (2005) A newly discovered mycobacterial pathogen isolated from laboratory colonies of Xenopus species with lethal infections produces a novel form of mycolactone, the Mycobacterium ulcerans macrolide toxin. Infect Immun 73(6):3307-3312

25. Ranger BS, Mahrous EA, Mosi L, Adusumilli S, Lee RE, Colorni A et al (2006) Globally distributed mycobacterial fish pathogens produce a novel plasmid-encoded toxic macrolide, mycolactone F. Infect Immun 74(11):6037-6045

26. Doig KD, Holt KE, Fyfe JA, Lavender CJ, Eddyani M, Portaels F et al (2012) On the origin of Mycobacterium ulcerans, the causative agent of Buruli ulcer. BMC Genomics 13:258

27. Kaser M, Rondini S, Naegeli M, Stinear T, Portaels F, Certa U et al (2007) Evolution of two distinct phylogenetic lineages of the emerging human pathogen Mycobacterium ulcerans. BMC Evol Biol 7:177

28. Eddyani M, De Jonckheere JF, Durnez L, Suykerbuyk P, Leirs H, Portaels F (2008) Occurrence of free-living amoebae in communities of low and high endemicity for Buruli ulcer in southern Benin. Appl Environ Microbiol 74(21):6547-6553

29. Gryseels S, Amissah D, Durnez L, Vandelannoote K, Leirs H, De Jonckheere J et al (2012) Amoebae as potential environmental hosts for Mycobacterium ulcerans and other mycobacteria, but doubtful actors in Buruli ulcer epidemiology. PLoS Negl Trop Dis 6(8):e1764

30. Amissah NA, Gryseels S, Tobias NJ, Ravadgar B, Suzuki M, Vandelannoote K et al (2014) Investigating the role of free-living amoebae as a reservoir for Mycobacterium ulcerans. PLoS Negl Trop Dis 8(9):e3148 
31. Trott KA, Stacy BA, Lifland BD, Diggs HE, Harland RM, Khokha MK et al (2004) Characterization of a Mycobacterium ulcerans-like infection in a colony of African tropical clawed frogs (Xenopus tropicalis). Comp Med 54(3):309-317

32. Rhodes MW, Kator H, McNabb A, Deshayes C, Reyrat JM, Brown-Elliott BA et al (2005) Mycobacterium pseudoshottsii sp. nov., a slowly growing chromogenic species isolated from Chesapeake Bay striped bass (Morone saxatilis). Int J Syst Evol Microbiol 55(Pt 3):1139-1147

33. Stragier P, Hermans K, Stinear T, Portaels F (2008) First report of a mycolactone-producing Mycobacterium infection in fish agriculture in Belgium. FEMS Microbiol Lett 286(1):93-95

34. Yoshida M, Nakanaga K, Ogura Y, Toyoda A, Ooka T, Kazumi Y et al (2016) Complete genome sequence of Mycobacterium ulcerans subsp. shinshuense. Genome Announc 4(5): $\mathrm{e} 01050-\mathrm{e} 01016$

35. Yip MJ, Porter JL, Fyfe JA, Lavender CJ, Portaels F, Rhodes M et al (2007) Evolution of Mycobacterium ulcerans and other mycolactone-producing mycobacteria from a common Mycobacterium marinum progenitor. J Bacteriol 189(5):2021-2029

36. Morris A, Gozlan R, Marion E, Marsollier L, Andreou D, Sanhueza D et al (2014) First detection of Mycobacterium ulcerans DNA in environmental samples from South America. PLoS Negl Trop Dis 8(1):e2660

37. Ohtsuka M, Kikuchi N, Yamamoto T, Suzutani T, Nakanaga K, Suzuki K et al (2014) Buruli ulcer caused by Mycobacterium ulcerans subsp shinshuense: a rare case of familial concurrent occurrence and detection of insertion sequence 2404 in Japan. JAMA Dermatol 150(1): 64-67

38. Boleira M, Lupi O, Lehman L, Asiedu KB, Kiszewski AE (2010) Buruli ulcer. An Bras Dermatol 85(3):281-298. quiz 99-301

39. Guerra H, Palomino JC, Falconi E, Bravo F, Donaires N, Van Marck E et al (2008) Mycobacterium ulcerans disease, Peru. Emerg Infect Dis 14(3):373-377

40. dos Santos VM, Noronha FL, Vicentina EC, Lima CC (2007) Mycobacterium ulcerans infection in Brazil. Med J Aust 187(1):63-64

41. Coloma JN, Navarrete-Franco G, Iribe P, Lopez-Cepeda LD (2005) Ulcerative cutaneous mycobacteriosis due to Mycobacterium ulcerans: report of two Mexican cases. Int J Lepr Other Mycobact Dis 73(1):5-12

42. Yotsu RR, Nakanaga K, Hoshino Y, Suzuki K, Ishii N (2012) Buruli ulcer and current situation in Japan: a new emerging cutaneous Mycobacterium infection. J Dermatol 39(7):587-593

43. Faber WR, Arias-Bouda LM, Zeegelaar JE, Kolk AH, Fonteyne PA, Toonstra J et al (2000) First reported case of Mycobacterium ulcerans infection in a patient from China. Trans R Soc Trop Med Hyg 94(3):277-279

44. Steffen CM, Freeborn H (2016) Mycobacterium ulcerans in the Daintree 2009-2015 and the mini-epidemic of 2011. ANZ J Surg 88(4):E289-E293

45. Reid IS (1967) Mycobacterium ulcerans infection: a report of 13 cases at the Port Moresby general hospital, Papua. Med J Aust 1(9):427-431

46. Radford AJ (1974) Mycobacterium Ulcerans infections in Papua New Guinea. P N G Med J 17(2):145-149

47. Merritt RW, Walker ED, Small PL, Wallace JR, Johnson PD, Benbow ME et al (2010) Ecology and transmission of Buruli ulcer disease: a systematic review. PLoS Negl Trop Dis 4(12):e911

48. Vandelannoote K, Durnez L, Amissah D, Gryseels S, Dodoo A, Yeboah S et al (2010) Application of real-time PCR in Ghana, a Buruli ulcer-endemic country, confirms the presence of Mycobacterium ulcerans in the environment. FEMS Microbiol Lett 304(2):191-194

49. Bratschi MW, Ruf MT, Andreoli A, Minyem JC, Kerber S, Wantong FG et al (2014) Mycobacterium ulcerans persistence at a village water source of Buruli ulcer patients. PLoS Negl Trop Dis 8(3):e2756

50. Fyfe JA, Lavender CJ, Handasyde KA, Legione AR, O’Brien CR, Stinear TP et al (2010) A major role for mammals in the ecology of Mycobacterium ulcerans. PLoS Negl Trop Dis 4(8):e791

51. Röltgen K, Pluschke G (2015) Mycobacterium ulcerans disease (Buruli ulcer): potential reservoirs and vectors. Curr Clin Microbiol Rep 2(1):35-43 
52. Roltgen K, Pluschke G, Johnson PDR, Fyfe J (2017) Mycobacterium ulcerans DNA in bandicoot excreta in Buruli ulcer-endemic area, northern Queensland, Australia. Emerg Infect Dis 23(12):2042-2045

53. Durnez L, Suykerbuyk P, Nicolas V, Barriere P, Verheyen E, Johnson CR et al (2010) Terrestrial small mammals as reservoirs of Mycobacterium ulcerans in Benin. Appl Environ Microbiol 76(13):4574-4577

54. Christie M (1987) Suspected Mycobacterium ulcerans disease in Kiribati. Med J Aust 146(11):600-604

55. Pettit JH, Marchette NJ, Rees RJ (1966) Mycobacterium ulcerans infection. Clinical and bacteriological study of the first cases recognized in South East Asia. Br J Dermatol 78(4): 187-197

56. N'krumah RT, Kone B, Cisse G, Tanner M, Utzinger J, Pluschke G et al (2016) Characteristics and epidemiological profile of Buruli ulcer in the district of Tiassale, south Cote d'Ivoire. Acta Trop 175:138-144

57. Hospers IC, Wiersma IC, Dijkstra PU, Stienstra Y, Etuaful S, Ampadu EO et al (2005) Distribution of Buruli ulcer lesions over body surface area in a large case series in Ghana: uncovering clues for mode of transmission. Trans R Soc Trop Med Hyg 99(3):196-201

58. Mensah-Quainoo E, Yeboah-Manu D, Asebi C, Patafuor F, Ofori-Adjei D, Junghanss T et al (2008) Diagnosis of Mycobacterium ulcerans infection (Buruli ulcer) at a treatment centre in Ghana: a retrospective analysis of laboratory results of clinically diagnosed cases. Tropical Med Int Health 13(2):191-198

59. Yeboah-Manu D, Aboagye SY, Asare P, Asante-Poku A, Ampah K, Danso E et al (2018) Laboratory confirmation of Buruli ulcer cases in Ghana, 2008-2016. PLoS Negl Trop Dis 12(6): 0006560

60. Debacker M, Aguiar J, Steunou C, Zinsou C, Meyers WM, Guedenon A et al (2004) Mycobacterium ulcerans disease (Buruli ulcer) in rural hospital, southern Benin, 1997-2001. Emerg Infect Dis 10(8):1391-1398

61. Vincent QB, Ardant MF, Adeye A, Goundote A, Saint-Andre JP, Cottin J et al (2014) Clinical epidemiology of laboratory-confirmed Buruli ulcer in Benin: a cohort study. Lancet Glob Health 2(7):e422-e430

62. Capela C, Sopoh GE, Houezo JG, Fiodessihoue R, Dossou AD, Costa P et al (2015) Clinical epidemiology of Buruli ulcer from Benin (2005-2013): effect of time-delay to diagnosis on clinical forms and severe phenotypes. PLoS Negl Trop Dis 9(9):e0004005

63. Noeske J, Kuaban C, Rondini S, Sorlin P, Ciaffi L, Mbuagbaw J et al (2004) Buruli ulcer disease in Cameroon rediscovered. Am J Trop Med Hyg 70(5):520-526

64. Bratschi MW, Bolz M, Minyem JC, Grize L, Wantong FG, Kerber S et al (2013) Geographic distribution, age pattern and sites of lesions in a cohort of Buruli ulcer patients from the Mape Basin of Cameroon. PLoS Negl Trop Dis 7(6):e2252

65. Mavinga Phanzu D, Suykerbuyk P, Saunderson P, Ngwala Lukanu P, Masamba Minuku JB, Imposo DB et al (2013) Burden of Mycobacterium ulcerans disease (Buruli ulcer) and the underreporting ratio in the territory of Songololo, Democratic Republic of Congo. PLoS Negl Trop Dis 7(12):e2563

66. Bretzel G, Huber KL, Kobara B, Beissner M, Piten E, Herbinger KH et al (2011) Laboratory confirmation of Buruli ulcer disease in Togo, 2007-2010. PLoS Negl Trop Dis 5(7):e1228

67. Marion E, Obvala D, Babonneau J, Kempf M, Asiedu KB, Marsollier L (2014) Buruli ulcer disease in Republic of the Congo. Emerg Infect Dis 20(6):1070-1072

68. Marion E, Carolan K, Adeye A, Kempf M, Chauty A, Marsollier L (2015) Buruli ulcer in South Western Nigeria: a retrospective cohort study of patients treated in Benin. PLoS Negl Trop Dis 9(1):e3443

69. Douine M, Gozlan R, Nacher M, Dufour J, Reynaud Y, Elguero E et al (2017) Mycobacterium ulcerans infection (Buruli ulcer) in French Guiana, South America, 1969-2013: an epidemiological study. Lancet Planet Health 1(2):e65-e73 
70. Steffen CM, Smith M, McBride WJ (2010) Mycobacterium ulcerans infection in North Queensland: the 'Daintree ulcer'. ANZ J Surg 80(10):732-736

71. Boyd SC, Athan E, Friedman ND, Hughes A, Walton A, Callan P et al (2012) Epidemiology, clinical features and diagnosis of Mycobacterium ulcerans in an Australian population. Med J Aust 196(5):341-344

72. Yerramilli A, Tay EL, Stewardson AJ, Kelley PG, Bishop E, Jenkin GA et al (2017) The location of Australian Buruli ulcer lesions-implications for unravelling disease transmission. PLoS Negl Trop Dis 11(8):e0005800

73. Ampah KA, Asare P, Binnah DD, Maccaulley S, Opare W, Roltgen K et al (2016) Burden and historical trend of Buruli ulcer prevalence in selected communities along the Offin River of Ghana. PLoS Negl Trop Dis 10(4):e0004603

74. Debacker M, Portaels F, Aguiar J, Steunou C, Zinsou C, Meyers W et al (2006) Risk factors for Buruli ulcer, Benin. Emerg Infect Dis 12(9):1325-1331

75. Johnson PD, Azuolas J, Lavender CJ, Wishart E, Stinear TP, Hayman JA et al (2007) Mycobacterium ulcerans in mosquitoes captured during outbreak of Buruli ulcer, southeastern Australia. Emerg Infect Dis 13(11):1653-1660

76. Debacker M, Aguiar J, Steunou C, Zinsou C, Meyers WM, Scott JT et al (2004) Mycobacterium ulcerans disease: role of age and gender in incidence and morbidity. Trop. Med Int Health 9(12):1297-1304

77. Roltgen K, Bratschi MW, Ross A, Aboagye SY, Ampah KA, Bolz M et al (2014) Late onset of the serological response against the $18 \mathrm{kDa}$ small heat shock protein of Mycobacterium ulcerans in children. PLoS Negl Trop Dis 8(5):e2904

78. Ampah KA, Nickel B, Asare P, Ross A, De-Graft D, Kerber S et al (2016) A Seroepidemiological approach to explore transmission of mycobacterium ulcerans. PLoS Negl Trop Dis 10(1):e0004387

79. Raghunathan PL, Whitney EA, Asamoa K, Stienstra Y, Taylor TH Jr, Amofah GK et al (2005) Risk factors for Buruli ulcer disease (Mycobacterium ulcerans infection): results from a casecontrol study in Ghana. Clin Infect Dis 40(10):1445-1453

80. Quek TY, Athan E, Henry MJ, Pasco JA, Redden-Hoare J, Hughes A et al (2007) Risk factors for Mycobacterium ulcerans infection, southeastern Australia. Emerg Infect Dis 13(11):1661-1666

81. Kenu E, Nyarko KM, Seefeld L, Ganu V, Kaser M, Lartey M et al (2014) Risk factors for buruli ulcer in Ghana-a case control study in the Suhum-Kraboa-Coaltar and Akuapem south districts of the eastern region. PLoS Negl Trop Dis 8(11):e3279

82. WHO (2012) Treatment of Mycobacterium ulcerans disease (Buruli ulcer): guidance for health workers. World Health Organization, Geneva

83. Chauty A, Ardant MF, Adeye A, Euverte H, Guedenon A, Johnson C et al (2007) Promising clinical efficacy of streptomycin-rifampin combination for treatment of buruli ulcer (Mycobacterium ulcerans disease). Antimicrob Agents Chemother 51(11): 4029-4035

84. Marion E, Song OR, Christophe T, Babonneau J, Fenistein D, Eyer J et al (2014) Mycobacterial toxin induces analgesia in buruli ulcer by targeting the angiotensin pathways. Cell 157(7):1565-1576

85. Morris A, Gozlan RE, Hassani H, Andreou D, Couppie P, Guegan JF (2014) Complex temporal climate signals drive the emergence of human water-borne disease. Emerg Microbes Infec 3:e56

86. Hudman LE, Jackson RH (2003) Geography of travel \& tourism, 4th edn. Thomson/Delmar Learning, Clifton Park. xi, 534 p., 8 p. of plates $p$

87. Buultjens AH, Vandelannoote K, Meehan CJ, Eddyani M, de Jong BC, Fyfe JAM et al (2018) Comparative genomics shows Mycobacterium ulcerans migration and expansion has preceded the rise of Buruli ulcer in South-Eastern Australia. Appl Environ Microbiol 84(8):e02612-e02617 
88. Carson C, Lavender CJ, Handasyde KA, O'Brien CR, Hewitt N, Johnson PD et al (2014) Potential wildlife sentinels for monitoring the endemic spread of human buruli ulcer in southEast Australia. PLoS Negl Trop Dis 8(1):e2668

89. Froidurot S, Diedhiou A (2017) Characteristics of wet and dry spells in the west African monsoon system. Atmos Sci Lett 18(3):125-131

90. Guenang GM, Kamga FM (2012) Onset, retreat and length of the rainy season over Cameroon. Atmos Sci Lett 13(2):120-127

91. Trubiano JA, Lavender CJ, Fyfe JA, Bittmann S, Johnson PD (2013) The incubation period of Buruli ulcer (Mycobacterium ulcerans infection). PLoS Negl Trop Dis 7(10):e2463

92. Loftus MJ, Trubiano JA, Tay EL, Lavender CJ, Globan M, Fyfe JAM et al (2018) The incubation period of Buruli ulcer (Mycobacterium ulcerans infection) in Victoria, Australia remains similar despite changing geographic distribution of disease. PLoS Negl Trop Dis 12(3):e0006323

93. Landier J, Constantin de Magny G, Garchitorena A, Guegan JF, Gaudart J, Marsollier L et al (2015) Seasonal patterns of Buruli ulcer incidence, Central Africa, 2002-2012. Emerg Infect Dis 21(8):1414-1417

94. Morse SS (1995) Factors in the emergence of infectious-diseases. Emerg Infect Dis 1(1): $7-15$

95. Patz JA, Olson SH, Uejio CK, Gibbs HK (2008) Disease emergence from global climate and land use change. Med Clin N Am 92(6):1473

96. Johnson PD, Veitch MG, Flood PE, Hayman JA (1995) Mycobacterium ulcerans infection on Phillip Island. Victoria Med J Aust 162(4):221-222

97. Oluwasanmi JO, Itayemi SO, Alabi GO (1975) Buruli (mycobacterial) ulcers in Caucasians in Nigeria. Brit J Plast Surg 28(2):111-113

98. Marion E, Landier J, Boisier P, Marsollier L, Fontanet A, Le Gall P et al (2011) Geographic expansion of Buruli ulcer disease, Cameroon. Emerg Infect Dis 17(3):551-553

99. N'Krumah RTAS, Kone B, Cisse G, Tanner M, Utzinger J, Pluschke G et al (2017) Characteristics and epidemiological profile of Buruli ulcer in the district of Tiassale, south cote d'Ivoire. Acta Trop 175:138-144

100. Brou T, Broutin H, Elguero E, Asse H, Guegan JF (2008) Landscape diversity related to Buruli ulcer disease in cote d'Ivoire. Plos Neglect Trop D 2(7):e271

101. Wu J, Tschakert P, Klutse E, Ferring D, Ricciardi V, Hausermann H et al (2015) Buruli ulcer disease and its association with land cover in southwestern Ghana. PLoS Negl Trop Dis 9(6): $\mathrm{e} 0003840$

102. N'Krumah RT, Kone B, Tiembre I, Cisse G, Pluschke G, Tanner M et al (2016) Socioenvironmental factors associated with the risk of contracting Buruli ulcer in Tiassale, south cote d'Ivoire: a case-control study. PLoS Negl Trop Dis 10(1):e0004327

103. Aboagye SY, Asare P, Otchere ID, Koka E, Mensah GE, Yirenya-Tawiah D et al (2017) Environmental and behavioral drivers of Buruli ulcer disease in selected communities along the Densu River basin of Ghana: a case-control study. Am J Trop Med Hyg 96(5): 1076-1083

104. Aiga H, Amano T, Cairncross S, Adomako J, Nanas OK, Coleman S (2004) Assessing waterrelated risk factors for Buruli ulcer: a case-control study in Ghana. Am J Trop Med Hyg 71(4):387-392

105. Sopoh GE, Barogui YT, Johnson RC, Dossou AD, Makoutode M, Anagonou SY et al (2010) Family relationship, water contact and occurrence of Buruli ulcer in Benin. PLoS Negl Trop Dis 4(7): 746

106. Maman I, Tchacondo T, Kere AB, Piten E, Beissner M, Kobara Y et al (2018) Risk factors for Mycobacterium ulcerans infection (Buruli ulcer) in Togo horizontal line a case-control study in Zio and Yoto districts of the maritime region. BMC Infect Dis 18(1):48

107. Hinds DA, Stuve LL, Nilsen GB, Halperin E, Eskin E, Ballinger DG et al (2005) Wholegenome patterns of common DNA variation in three human populations. Science 307(5712):1072-1079 
108. Menashe I, Rosenberg PS, Chen BE (2008) PGA: power calculator for case-control genetic association analyses. BMC Genet 9:36

109. Bibert S, Bratschi MW, Aboagye SY, Collinet E, Scherr N, Yeboah-Manu D et al (2017) Susceptibility to Mycobacterium ulcerans disease (Buruli ulcer) is associated with IFNG and iNOS gene polymorphisms. Front Microbiol 8:1903

110. Stienstra Y, van der Werf TS, Oosterom E, Nolte IM, van der Graaf WT, Etuaful S et al (2006) Susceptibility to Buruli ulcer is associated with the SLC11A1 (NRAMP1) D543N polymorphism. Genes Immun 7(3):185-189

111. Capela C, Dossou AD, Silva-Gomes R, Sopoh GE, Makoutode M, Menino JF et al (2016) Genetic variation in autophagy-related genes influences the risk and phenotype of Buruli ulcer. PLoS Negl Trop Dis 10(4):e0004671

112. Goswami T, Bhattacharjee A, Babal P, Searle S, Moore E, Li M et al (2001) Naturalresistance-associated macrophage protein 1 is an $\mathrm{H}+/$ bivalent cation antiporter. Biochem $\mathrm{J}$ 354(Pt 3):511-519

113. Manzanillo PS, Ayres JS, Watson RO, Collins AC, Souza G, Rae CS et al (2013) The ubiquitin ligase parkin mediates resistance to intracellular pathogens. Nature 501(7468): 512-516

114. Zimmermann P, Finn A, Curtis N (2018) Does BCG vaccination protect against nonTuberculous mycobacterial infection? A systematic review and meta-analysis. J Infect Dis 218(5):679-687

115. The Uganda Buruli group (1969) BCG vaccination against mycobacterium ulcerans infection (Buruli ulcer). First results of a trial in Uganda. Lancet 1(7586):111-5

116. Smith PG, Revill WD, Lukwago E, Rykushin YP (1976) The protective effect of BCG against Mycobacterium ulcerans disease: a controlled trial in an endemic area of Uganda. Trans $\mathrm{R}$ Soc Trop Med Hyg 70(5-6):449-457

117. Nackers F, Dramaix M, Johnson RC, Zinsou C, Robert A (2006) E DEBB, et al. BCG vaccine effectiveness against Buruli ulcer: a case-control study in Benin. Am J Trop Med Hyg 75(4):768-774

118. Phillips RO, Phanzu DM, Beissner M, Badziklou K, Luzolo EK, Sarfo FS et al (2015) Effectiveness of routine BCG vaccination on buruli ulcer disease: a case-control study in the Democratic Republic of Congo, Ghana and Togo. PLoS Negl Trop Dis 9(1):e3457

119. Ahoua L, Guetta AN, Ekaza E, Bouzid S, N'Guessan R, Dosso M (2009) Risk factors for Buruli ulcer in cote d'Ivoire: results of a case-control study, august 2001. Afr J Biotechnol 8(4):536-546

120. Johnson RC, Nackers F, Glynn JR, de Biurrun Bakedano E, Zinsou C, Aguiar J et al (2008) Association of HIV infection and Mycobacterium ulcerans disease in Benin. AIDS 22(7):901-903

121. Christinet V, Comte E, Ciaffi L, Odermatt P, Serafini M, Antierens A et al (2014) Impact of human immunodeficiency virus on the severity of buruli ulcer disease: results of a retrospective study in Cameroon. Open Forum Infect Dis 1(1):ofu021

122. Tuffour J, Owusu-Mireku E, Ruf MT, Aboagye S, Kpeli G, Akuoku V et al (2015) Challenges associated with Management of Buruli Ulcer/human immunodeficiency virus Coinfection in a treatment Center in Ghana: a case series study. Am J Trop Med Hyg 93(2): 216-223

123. Bayonne Manou LS, Portaels F, Eddyani M, Book AU, Vandelannoote K, de Jong BC (2013) Mycobacterium ulcerans disease (Buruli ulcer) in Gabon: 2005-2011. Med Sante Trop 23(4):450-457

124. Toll A, Gallardo F, Ferran M, Gilaberte M, Iglesias M, Gimeno JL et al (2005) Aggressive multifocal Buruli ulcer with associated osteomyelitis in an HIV-positive patient. Clin Exp Dermatol 30(6):649-651

125. Komenan K, Elidje EJ, Ildevert GP, Yao KI, Kanga K, Kouame KA et al (2013) Multifocal Buruli ulcer associated with secondary infection in HIV positive patient. Case Rep Med 2013:348628 
126. Johnson RC, Ifebe D, Hans-Moevi A, Kestens L, Houessou R, Guedenon A et al (2002) Disseminated Mycobacterium ulcerans disease in an HIV-positive patient: a case study. AIDS 16(12):1704-1705

127. Bafende AE, Lukanu NP, Numbi AN (2002) Buruli ulcer in an AIDS patient. S Afr Med J 92(6):437

128. Kibadi K, Colebunders R, Muyembe-Tamfum JJ, Meyers WM, Portaels F (2010) Buruli ulcer lesions in HIV-positive patient. Emerg Infect Dis 16(4):738-739

129. O'Brien DP, Ford N, Vitoria M, Christinet V, Comte E, Calmy A et al (2014) Management of BU-HIV co-infection. Tropical Med Int Health 19(9):1040-1047

130. Junghanss T, Johnson RC, Pluschke G (2014) Mycobacterium ulcerans disease. In: Farrar J, Hotez PJ, Junghanss T, Kang G, Lalloo D, White NJ (eds) Manson's tropical diseases, 23rd edn. Saunders, Edinburgh, pp 519-531

131. Nakanaga K, Hoshino Y, Yotsu RR, Makino M, Ishii N (2011) Nineteen cases of Buruli ulcer diagnosed in Japan from 1980 to 2010. J Clin Microbiol 49(11):3829-3836

132. Fyfe JA, Lavender CJ, Johnson PD, Globan M, Sievers A, Azuolas J et al (2007) Development and application of two multiplex real-time PCR assays for the detection of Mycobacterium ulcerans in clinical and environmental samples. Appl Environ Microbiol 73(15):4733-4740

133. Klis S, Stienstra Y, Phillips RO, Abass KM, Tuah W, van der Werf TS (2014) Long term streptomycin toxicity in the treatment of Buruli ulcer: follow-up of participants in the BURULICO drug trial. PLoS Negl Trop Dis 8(3):e2739

134. O'Brien DP, Jenkin G, Buntine J, Steffen CM, McDonald A, Horne S et al (2014) Treatment and prevention of Mycobacterium ulcerans infection (Buruli ulcer) in Australia: guideline update. Med J Aust 200(5):267-270

135. Vogel M, Bayi PF, Ruf MT, Bratschi MW, Bolz M, Um Boock A et al (2016) Local heat application for the treatment of Buruli ulcer: results of a phase II open label single center non comparative clinical trial. Clin Infect Dis 62(3):342-350

136. Renzaho AM, Woods PV, Ackumey MM, Harvey SK, Kotin J (2007) Community-based study on knowledge, attitude and practice on the mode of transmission, prevention and treatment of the Buruli ulcer in Ga West District, Ghana. Tropical Med Int Health 12(3): $445-458$

137. Mulder AA, Boerma RP, Barogui Y, Zinsou C, Johnson RC, Gbovi J et al (2008) Healthcare seeking behaviour for Buruli ulcer in Benin: a model to capture therapy choice of patients and healthy community members. Trans R Soc Trop Med Hyg 102(9):912-920

138. Koka E, Yeboah-Manu D, Okyere D, Adongo PB, Ahorlu CK (2016) Cultural understanding of wounds, Buruli ulcers and their Management at the Obom sub-district of the Ga south municipality of the Greater Accra region of Ghana. PLoS Negl Trop Dis 10(7):e0004825

139. Peeters Grietens K, Toomer E, Um Boock A, Hausmann-Muela S, Peeters H, Kanobana $\mathrm{K}$ et al (2012) What role do traditional beliefs play in treatment seeking and delay for Buruli ulcer disease?--insights from a mixed methods study in Cameroon. PLoS One 7(5): e36954

140. Grietens KP, Boock AU, Peeters H, Hausmann-Muela S, Toomer E, Ribera JM (2008) "It is me who endures but my family that suffers": social isolation as a consequence of the household cost burden of Buruli ulcer free of charge hospital treatment. PLoS Negl Trop Dis 2(10):e321

141. Amoakoh HB, Aikins M (2013) Household cost of out-patient treatment of Buruli ulcer in Ghana: a case study of Obom in Ga south municipality. BMC Health Serv Res 13:507

142. Chukwu JN, Meka AO, Nwafor CC, Oshi DC, Madichie NO, Ekeke N et al (2017) Financial burden of health care for Buruli ulcer patients in Nigeria: the patients' perspective. Int Health 9(1):36-43

143. Amoussouhoui AS, Sopoh GE, Wadagni AC, Johnson RC, Aoulou P, Agbo IE et al (2018) Implementation of a decentralized community-based treatment program to improve the management of Buruli ulcer in the Ouinhi district of Benin, West Africa. PLoS Negl Trop Dis 12(3): 0006291 
144. Ayelo GA, Anagonou E, Wadagni AC, Barogui YT, Dossou AD, Houezo JG et al (2018) Report of a series of 82 cases of Buruli ulcer from Nigeria treated in Benin, from 2006 to 2016. PLoS Negl Trop Dis 12(3):e0006358

145. Tabah EN, Nsagha DS, Bissek AC, Njamnshi AK, Bratschi MW, Pluschke G et al (2016) Buruli ulcer in Cameroon: the development and impact of the national control Programme. PLoS Negl Trop Dis 10(1):e0004224

146. Mitja O, Marks M, Bertran L, Kollie K, Argaw D, Fahal AH et al (2017) Integrated control and Management of Neglected Tropical Skin Diseases. PLoS Negl Trop Dis 11(1):e0005136

147. Barogui YT, Diez G, Anagonou E, Johnson RC, Gomido IC, Amoukpo H et al (2018) Integrated approach in the control and management of skin neglected tropical diseases in Lalo, Benin. PLoS Negl Trop Dis 12(6):e0006584

Open Access This chapter is licensed under the terms of the Creative Commons Attribution 4.0 International License (http://creativecommons.org/licenses/by/4.0/), which permits use, sharing, adaptation, distribution and reproduction in any medium or format, as long as you give appropriate credit to the original author(s) and the source, provide a link to the Creative Commons license and indicate if changes were made.

The images or other third party material in this chapter are included in the chapter's Creative Commons license, unless indicated otherwise in a credit line to the material. If material is not included in the chapter's Creative Commons license and your intended use is not permitted by statutory regulation or exceeds the permitted use, you will need to obtain permission directly from the copyright holder.

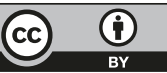

